\title{
Stenaptinus (Coleoptera: Carabidae: Brachininae) of Vietnam. Note 2
}

\section{Stenaptinus (Coleoptera: Carabidae: Brachininae) Вьетнама. Сообщение 2}

\author{
D.N. Fedorenko \\ A.H. Федоренко
}

A.N. Severtsov Institute of ecology and evolution, Leninsky pr. 33, Moscow 119071 Russia. E-mail: dmitri-fedorenko@yandex.ru Институт проблем экологии и эволюции им. А.Н. Северцова, Российская Академия Наук, Ленинский пр-т, Москва 119071 Россия,

KEY WORDS: Coleoptera, Carabidae, Brachininae, Stenaptinus, new species, new subspecies, new synonym, Vietnam, Oriental region.

КЛЮЧЕВЫЕ СЛОВА: Coleoptera, Carabidae, Stenaptinus, новый вид, новый подвид, новый синоним, Вьетнам, Ориентальная область.

\begin{abstract}
Nine species of the javanus species group of the genus Stenaptinus Maindron, 1906 from Vietnam are reviewed and a key to the species is provided. Two new species, $S$. dongnaiensis sp.n. from Vietnam and S. sumatrensis sp.n. from Sumatra, and a new subspecies, $S$. consularis flaviceps ssp.n. from Vietnam, are described. Three species, S. agnatus (Chaudoir, 1876), stat.rest., S. fimbriatus (Chaudoir, 1876), stat.rest., and S. stenoderus (Chaudoir, $1850)$ are resurrected from synonymy of either $S$. javanus (Dejean, 1825) or S. consularis (SchmidtGöbel, 1846). New synonymy is established: $S$. lissoderus (Chaudoir, 1850) $=S$. picicollis (Chaudoir, 1876), syn.n.; S. stenoderus $=$ S. lei (Hrdlička, 2019), syn.n.; = S. snizeki (Hrdlička, 2019), syn.n.; S. agnatus $=$ S. suensoni $($ Schauberger, 1923); = S. worthingtoni (Hrdlička, 2019), syn.n.
\end{abstract}

РЕЗЮМЕ. Дан обзор 9 вьетнамских видов рода Stenaptinus Maindron, 1906 из группы 'javanus'; составлена таблица для их определения. Описаны два новых вида и новый подвид: S. dongnaiensis sp.n. и $S$. consularis flaviceps ssp.n. из Вьетнама и $S$. sumatrensis sp.n. с Суматры. Три вида - S. agnatus (Chaudoir, 1876), stat.rest., S. fimbriatus (Chaudoir, 1876), stat.rest., и S. stenoderus (Chaudoir, 1850) восстановлены из синонимов $S$. javanus (Dejean, 1825) и S. consularis (Schmidt-Göbel, 1846). Установлена новая синонимия: S. lissoderus (Chaudoir, $1850)=S$. picicollis (Chaudoir, 1876), syn.n.; S. stenoderus $=S$. lei (Hrdlička, 2019), syn.n.; $=S$. snizeki (Hrdlička, 2019), syn.n.; S. agnatus $=S$. suensoni (Schauberger, 1923); = S. worthingtoni (Hrdlička, 2019), syn.n.

\section{Introduction}

The bidoupensis-group and dissolutus-group of the the genus Stenaptinus Maindron, 1906 (Brachinini, Brachininae, Carabidae) have been reviewed just recently [Fedorenko, 2020]. In this paper we review the species of the javanus species group from Vietnam, describe two new species and one new subspecies and revise some others based chiefly on comparative analysis of male and female genitalia.

Acronyms used are as follows: EASC — East Asia Terrestrial Biodiversity Scientific Center, Vladivostok; MNHN - Museum National d'Histoire Naturelle, Paris; MSPU — the Moscow State Pedagocical University; SIEE - the author's reference collection at A.N. Severtsov Institute of Ecology \& Evolution, Russian Academy of Sciences, Moscow; ZISP - Zoological Institute, Russian Academy of Sciences, St. Petersburg; ZMMU - Zoological Museum of the Moscow State University; ZSM - Siberian Zoological Museum, Novosibirsk.

The following parameters and ratios (Table) were analyzed: maximum body length measured between apices of closed mandibles and sutural angle of elytra (BL); length of elytron, measured from the highest point of basal margin to sutural angle (EL); maximum width of elytra (EW); width of head across eyes (HW); length of eye in sagittal plane (OL); width of pronotum between apical (PA) or basal (PB) angles; length of pronotum along median line (PL); distance between pronotal apex and level of maximum width of pronotum, measured along mid-line (PLw); maximum width of pronotum (PW). The measurements were taken using an eyepiece micrometer, to two decimal places. The means are given in round brackets for the ratios. All labels are printed unless other-

How to cite this article: Fedorenko D.N. 2021. Stenaptinus (Coleoptera: Carabidae: Brachininae) of Vietnam. Note 2 // Russian Entomol. J. Vol.30. No.1. P.25-42. doi: 10.15298/rusentj.30.1.05 
wise specified in square brackets. Data on labels of type specimens are in quotes; slash shows new line.

Male aedeagi were examined dried or with internal sac everted and maximally inflated with air and then airdried; female genitalia were examined either dried or placed in glycerin, after being boiled for two minutes or put for a day in a diluted $\mathrm{KOH}$ solution and then rinsed.

Elytral interval means depressed area between adjacent longitudinal ridges.

\section{Results}

\section{Stenaptinus Maindron, 1906}

The javanus species group.

DIAGNOSIS. Body variegated (Figs 71-111), nearly glabrous dorsally, with very short individual setae scattered over elytral disc, without or with similar setae at pronotal base and/or at apex, and near supra-ocular seta. Head mostly pale, with a contrastingly darker $\mathrm{V}$ - or U-, or Y-shaped, patch between eyes; this patch mostly extended onto neck and often reaching pronotum.

Pronotum impunctate or with very few large punctures; when present, dark median stripe not or barely wider in apical than in basal half. Prosternum and propleura glabrous except 2-6 strong paramedian setae between procoxae.
Elytra subparallel-sided, with humeri distinct to trapezoidal, in the latter case much broader apically than basally due to humeri imperceptible; ridges wide and slightly convex. Elytral pale pattern generally consisting of large to missing humeral spot, transverse median band, rather narrow lateral margin, and apical margin. Transverse median band more or less strongly dentate at even ridges anteriorly and at odd ridges posteriorly, inwardly reaching ridge 2 ; apical margin mostly narrow or missing, in the latter case only including apices of elytral ridges.

Body mostly macropterous, sometimes ( $S$. stenoderus and $S$. marginicollis) apterous. In some populations of $S$. javanus, brachypterous adults have also been observed.

Profemora laterally tumid in male.

Abdominal apical urites (Figs 1-20): In female, tergite VII with 9-17 rather strong setae; tergite VIII with median sclerotization (psm) transvere subrectangular, apical depigmented region ( $\boldsymbol{a d r}$ ) long, densely tuberculate and setulose; sternite VIII densely pubescent, without medioapical sclerite, with a membranous area just in front of 14-20 strong apical setae and inner internal carina running close to re-entrant angle between base and laterobasal apophysis. Sternite VII bisetose to quadrisetose in male.

Median lobe of aedeagus with apex round in crosssection to flattened dorsoventrally, mostly finely carinate ventro-apically.

Urite IX evenly membranous ventrally (Figs 56-64) in female; gonocoxite moderately long, glabrous at dorsal edges.

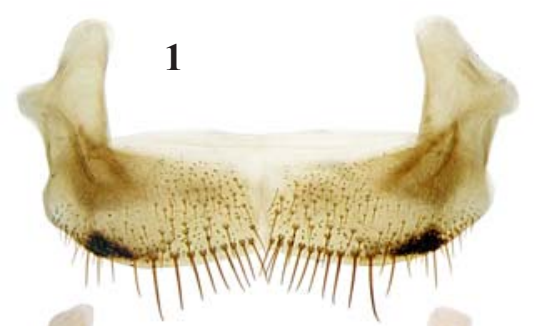

4
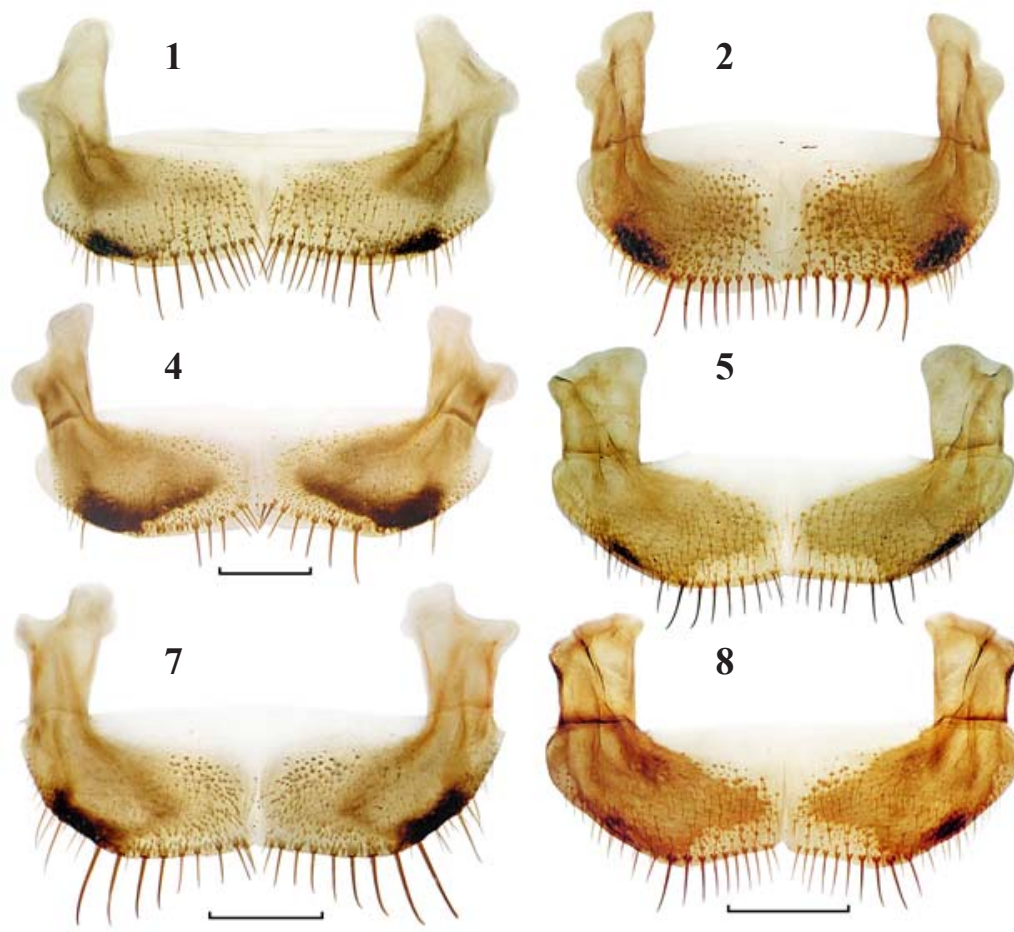

5

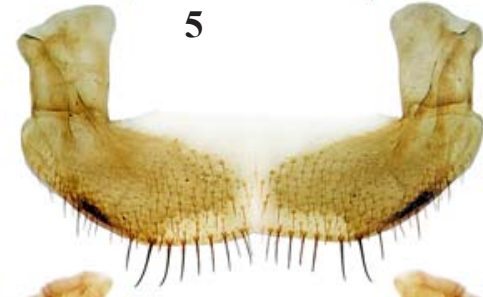

8
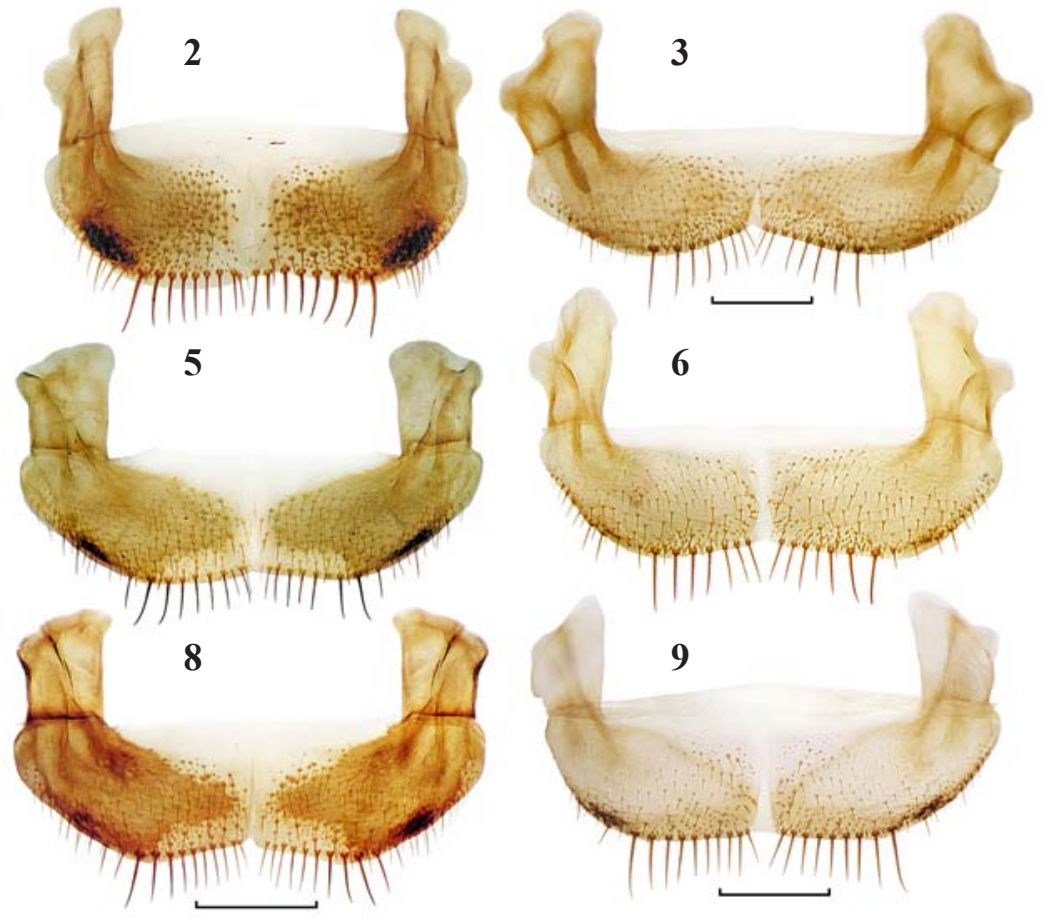

6

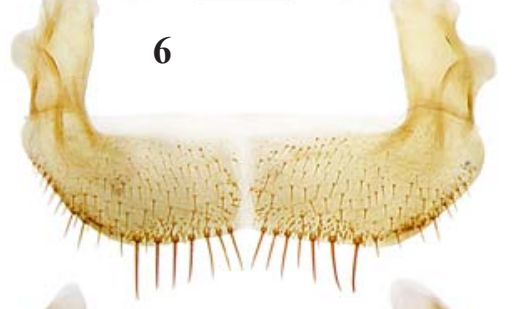

9

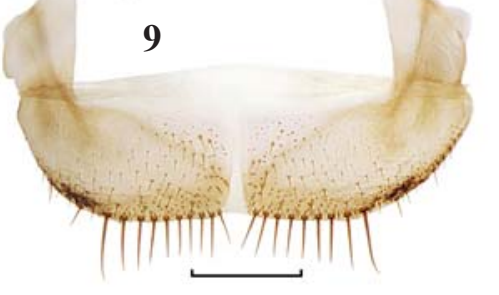

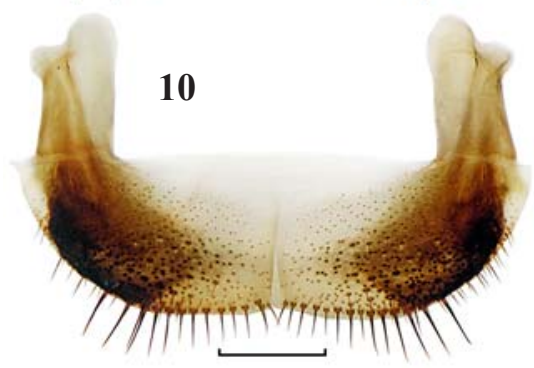

Figs 1-10. Stenaptinus spp., sternite VIII in female: $1-S$. stenoderus; $2-S$. lissoderus; 3, $6-S$. agnatus from Cat Tien; $4-S$. sumatrensis sp.n.; $5-S$. c. consularis; $6-S$. montanus sp.n.; $7-$ S. fimbriatus; $8-$ S. consularis flaviceps ssp.n.; $9-$ S. javanus; $10-S$. marginicollis. Scale bars: $1 \mathrm{~mm}$.

Рис. 1-10. Stenaptinus spp., стернит VIII самки: $1-S$. stenoderus; $2-S$. lissoderus; 3, $6-S$. agnatus из Катьена; $4-S$. sumatrensis sp.n.; $5-$ S. c. consularis; $6-S$. montanus sp.n.; $7-S$. fimbriatus; $8-S$. consularis flaviceps ssp.n.; $9-S$. javanus; $10-S$. marginicollis. Масштаб: 1 мм. 
Spermathecal receptacle from Y-shaped, with horns unequal in length, to bulbous, with one horn tumid and the other totally absorbed (Figs 56-70).

GEOGRAPHIC DISTRIBUTION. Throughout the Paleotropical realm and southern Palearctic subregion in southern Europe and East Asia. The group is much more diverse in the Oriental than in Afrotropical region. All the Oriental species are widespread.

HABITATS AND HABITS. The adults are nocturnal carnivores generally found in open habitats in lowlands and piedmonts. Many species are frequent on bogs and by pools in floodlands or along rivers and larger streams, including in plant debris on riverbanks. Some of them occur also along forest edges, wood trails and even roads. Macropterous species often flight to light at night. Sympatric species of the group often live syntopically.

COMMENTS. This group includes ten species in the Oriental region north to the East Asian Palearctic subregion, with some others occurring in the Afrotropical and Madagascan regions; S. hispanicus (Dejean, 1824) from southwestern Paleactic is most likely to belong to the group, too.

Most of these species are very similar in appearance, including body shape, proportions and colour pattern. Because the pattern varies greatly between individuals as well as between local populations of a species, particular color morphs being often observed in different species. As a result, the species of the group are hard to determine, and examination of the male genitalia is very advisable for the purpose.
The group is here divided into the javanus-subgroup and the fimbriatus-subgroup, based chiefly on a particular groundplan of the internal sac of aedeagus.

The javanus-subgroup includes six Oriental species $(S$. javanus, S. fumigatus, S. lissoderus, S. consularis, $S$. stenoderus, and S. marginicollis) and a few Afrotropical and Madagascan ones, including S. humeralis Chaudoir, 1843 and $S$. madagascariensis Dejean, 1825. The internal sac is asymmetrical in all of them because a well-developed left distal basal bulb is present (Figs 21-42). The internal sac is more or less straight (Figs 23, 25, 30, 32, 34, 37, 41) or geniculate ( $S$. javanus), with membranous apex starting from below the apex of, and perpendicular to, the body of the internal sac. A well defined apex of the body of the internal sac (Figs 21, 23, 27) makes S. javanus, S. marginicollis and S. madagascariensis similar. Four species with straight internal sac have an additional preapical frontal bulb which is either distinct (S. fumigatus, S. stenoderus, S. lissoderus) or vague to missing ( $S$. consularis). Spermathecal receptacle is asymmetric Y-shaped. Aedeagus apex is either pointed $(S$. javanus, S. lissoderus) or blunt and mostly slightly S-shaped in dorsal view, with ventro-apical carina either missing ( $S$. lissoderus, S. marginicollis) or distinct.

The fimbriatus-subgroup includes four species: $S$. fimbriatus, $S$. dongnaiensis sp.n., S. sumatrensis sp.n., and $S$. agnatus. The former three are closely related, as they have the internal sac of aedeagus symmetrical, with distal basal bulbs missing (Figs 48-55), and spermathecal receptacle peculiar,
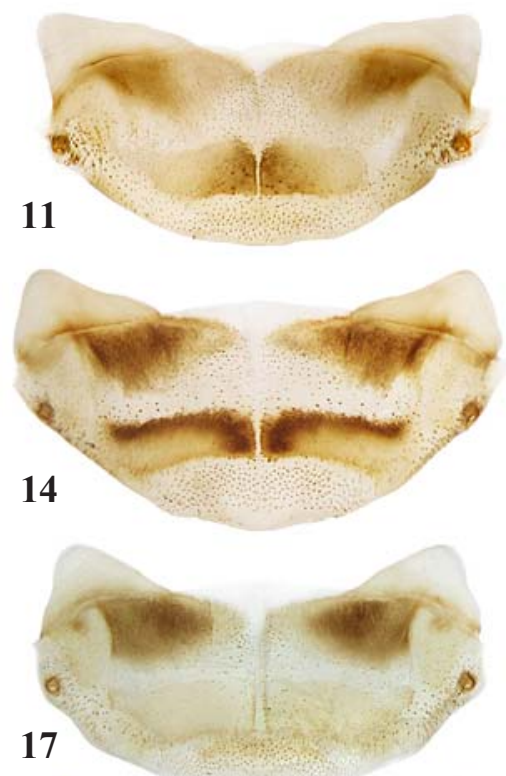

17

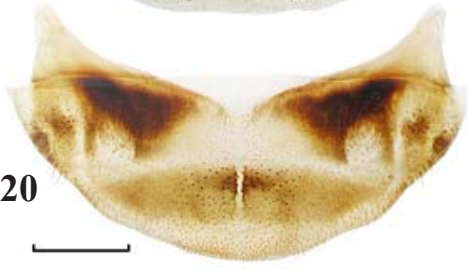

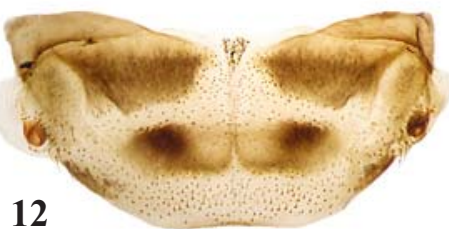
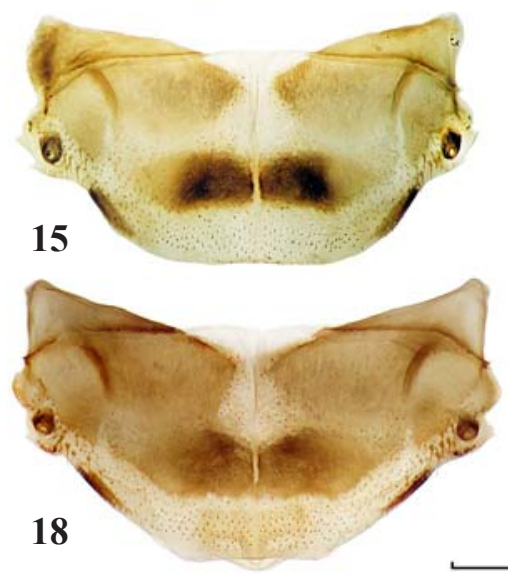

13
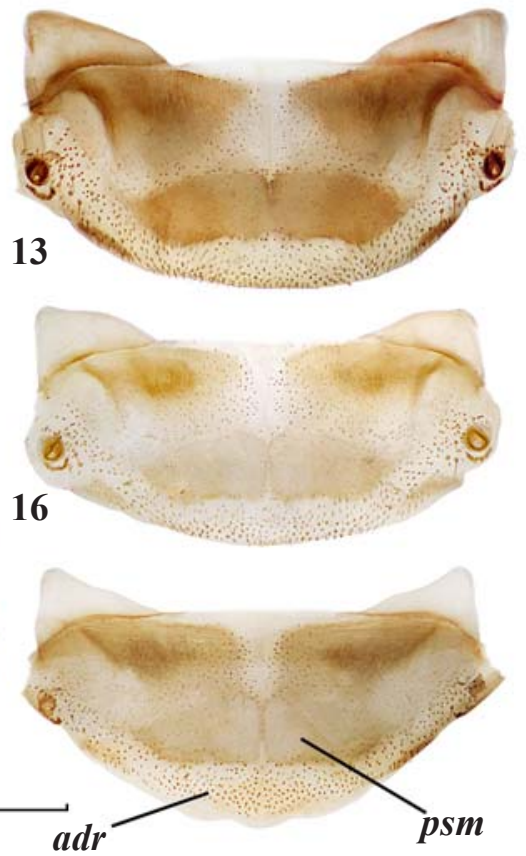

19

Figs 11-20. Stenaptinus spp., tergite VIII in female: 11 - S. stenoderus; 12 - S. lissoderus; 13,16 - S. agnatus from Cat Tien; $14-$ S. sumatrensis sp.n.; $15-$ S. c. consularis; $16-$ S. montanus sp.n.; $17-$ S. fimbriatus; $18-$ S. consularis flaviceps ssp.n.; $19-$ S. javanus; 20 - S. marginicollis; adr - apical depigmented region; psm - posteromedian sclerotized region. Scale bars: $1 \mathrm{~mm}$.

Рис. 11-20. Stenaptinus spp., тергит VIII самки: $11-$ S. stenoderus; $12-$ S. lissoderus; $13,16-S$. agnatus из Катьена; $14-S$. sumatrensis sp.n.; $15-$ S. c. consularis; $16-$ S. montanus sp.n.; $17-$ S. fimbriatus; $18-$ S. consularis flaviceps ssp.n.; $19-$ S. javanus; 20 - S. marginicollis; adr - апикальная депигментированная область; psm - постеро-медиальная склеротизация. Масштаб: 1 мм. 
bulbous (Figs 66-70). Stenaptinus agnatus is somewhat intermediate between the two subgroups. It has the apex of aedeagus median lobe and spermathecal receptacle similar to those in the javanus-subgroup (Figs 43, 44, 47, 69), and a vestigial left distal bulb is sometimes traceable (Figs 43, 47).

KEY TO SPECIES OF THE JAVANUS-GROUP (species not recorded in Vietnam are in square brackets).

1(2) Pronotum uniform red to black, without or with brown lateral margins, rarely with vague traces of pale spots (Figs 98-102). Head red or at least entire frons and vertex infuscated ............. [2. S. lissoderus (Chaudoir, 1850)]

2(1) Pronotum bicoloured, dark, with two paramedian yellow spots, to yellow, with margins or at least base and apex infuscated. Frons pale anterior to black patch between eyes.

3(4) Elytra subtriangular, much broader apically than basally, with humeri indistinct or almost so (Figs 96-97, 103105). Head with dark patch Y-shaped to pentagonal. Elytral median fascia not reaching lateral margin, mostly wide and only slightly dentate before and behind. Body apterous ....................... 4. S. stenoderus Chaudoir, 1850

4(3) Elytra subrectangular and more or less parallel-sided, with humeri rounded yet distinct; if notably broader apically than basally, then head with dark patch small Vshaped to missing. Body mostly macropterous or wings polymorphic.

5(6) Elytra uniform dark brown to black or with a minute pale humeral spot only; pronotum with rather small paramedian pale spots; black patch between eyes parallel-sided and extended to pronotum. - The Philippines ..............

[S. fumigatus (Dejean, 1825)]

6(5) Elytra bicoloured, black, with pale median spot or transverse band, smaller humeral spot and often also narrow to wide apical margin.

7(10) Head without or with a small black patch between eyes.

8(9) Black patch V-shaped to missing (Figs 90-94). Median lobe of aedeagus with apex blunt and strongly bent ventrad ........... 3. S. consularis (Schmidt-Göbel, 1846)

a(b) Elytra short (EL/EW 1.44-1.53) and wider relative to rather narrow pronotum, pronotal base narrower. Head with black V-shaped patch distinct to vague; pronotum and elytra with black colour prevailing due to pronotal pale spots narrow and separate, elytral transvere band narrow and isolated from lateral margin, and apices of elytral ridges only pale (Figs 90-92) 3a. S. c. consularis (Schmidt-Göbel, 1846)

b(a) Elytra longer and narrower (EL/EW 1.52-1.66), pronotum and its base slightly wider. Head entirely pale, pronotum yellow, with base, apex and lateral beads black only; elytron with pale transverse band and apical margin both wide and confluent along lateral margin or along interval 8 (Figs 93-94) ........................ 3b. S. c. flaviceps ssp.n.

9(8) Head with a small subtransverse spot (Figs 106-107). Median lobe of aedeagus (Fig. 55) and abdominal sternites as in couplet 11 ............... 7. S. dongnaiensis sp.n.

10(7) Black patch large, sometimes V-shaped to missing (in some specimens of $S$. agnatus).

11(14) Head with black patch reaching pronotum, parallelsided to occupying entire neck (Figs 77-81, 108-109).

12(13) Pronotal paramedian spots large, mostly reaching lateral margins. Elytron with transverse median band mostly wide or very wide. Aedeagus apex large, tapered in lateral view, with a minute and very pointed apical beak in dorsal view (Fig. 48). Female tergite VII with apical setae very strong and apically unciform or almost so; tergite VII with apical tuberculate area abruptly separated from smooth region in front. Sternite VII quadrisetose in male ......... 6. S. fimbriatus (Chaudoir, 1876)

13(12) Colour pattern as in melanistic specimens of S. fimbriatus (Figs 108-109). Aedeagus, including internal sac, as in $S$. dongnaiensis sp.n., except for proximal basal bulbs invisible in dorsal view .............. 8. S. sumatrensis sp.n.

14(11) Head with black patch subtransverse to Y-shaped, reaching pronotum or not (Figs 74-76, 82-89, 95). Tergite VII with apical setae rather short and straight in female; sternite VII mostly bisetose in male.

15(16) Head with black patch rather small, transverse, parallel-sided, V-shaped at anterior and posterior margins. Pronotum pale, with black margins, and more or less rugulose. Body apterous

[9. S. marginicollis (Motschulsky, 1854)]

16(15) Head with black patch well-developed, generally Yshaped. Body macropterous or brachypterous.

17(18) Apex of aedeagus median lobe wide in dorsal view; internal sac asymmetric, with left distal basal bulb conspicuous (Figs 27-28). Elytral transverse band mostly narrow. Body macropterous or brachypterous .....

1. S. javanus (Dejean, 1825)

18(17) Apex of aedeagus median lobe narrow in dorsal view; internal sac nearly symmetric, with left distal basal bulb missing or rudimentary (Figs 43-47). Elytral transverse band mostly wide. Body macropterous

5. S. agnatus (Chaudoir, 1876)

\section{Stenaptinus javanus (Dejean, 1825)}

Figs 9, 19, 27-28, 59, 67, 74-76.

Dejean, 1825: 305 (Brachinus; Java); Chaudoir, 1876: 18, 42 (Pheropsophus; part.); Andrewes, 1930: 273 (part.); 1933: 365; Louwerens, 1953: 318; Jedlička, 1964: 529 (part.); Habu, 1967: 291; 1984: 123 (part.); Darlington, 1968: 235; Hrdlička, 2017: 480 (part.).

MATERIAL. Syntype + (MNHN, digital images) with labels: 'javanus. m/ h. in inf. Java' [yellow label with handwritten text]; 'G. J. Arrow/ vidit 1901'; 'Ex Musaeo/ Chaudoir'.

Additional material (SIEE): $\sigma^{\urcorner}, \mathrm{S}$ Vietnam, Dong Nai Province, $\sim 90 \mathrm{~km}$ ENE of Saigon (N. Belyaeva); $4 \sigma^{\top} \sigma^{7}, 2+9$, Lam Dong Province, $25 \mathrm{~km}$ NNW of Bao Loc, Loc Bao env., 11 ${ }^{\circ} 44^{\prime} 18^{\prime \prime} \mathrm{N} /$ $107^{\circ} 42^{\prime} 08^{\prime \prime} \mathrm{E}, \mathrm{h}=800 \mathrm{~m}$ 5-20.IV.2013 (D. Fedorenko); + , Ha Tinh Province, Ke Go Nature Reserve, $18^{\circ} 06^{\prime} 30^{\prime \prime} \mathrm{N} / 106^{\circ} 01^{\prime} \mathrm{E}$, env. Mui Tru Station, h=40 m, 7-14.V.2015 (A. Abramov); O (MSPU), Hanoi, 15.I.1962 (collector unknown); $O^{7}$, N Thailand, Chiang Rai Province, env. Mae Suai, $19^{\circ} 39^{\prime} 16^{\prime \prime} \mathrm{N} / 9^{\circ} 32^{\prime} 54^{\prime \prime} \mathrm{E}, \mathrm{h}=450 \mathrm{~m}, 10$ 11.V.2013 (I. Melnik); $20^{7} \sigma^{7}$, Bangkok, Rajitani villa, Ciong Liang, $14^{\circ} 41^{\prime} \mathrm{N} / 102^{\circ} 27^{\prime} 15^{\prime \prime} \mathrm{E}$, at light, 20.XII.2007-10.I.2008 (A. Korshunov); $O^{\top}$ (SZM): Nakhon Ratchasima Province (Korat), Saeng Sang, Lam Sae Dam, Tha Plan National Park, h=250 m, 14 $16^{\prime} 40^{\prime \prime} \mathrm{N} /$ $102^{\circ} 25^{\prime} 28.5^{\prime \prime E}, 7-8.06 .2010$ (A. Korshunov); ㅇ, Borneo, Sabah, $80 \mathrm{~km} \mathrm{~W}$ of Lahad Datu, 04 $58^{\prime} \mathrm{N} / 117^{\circ} 48^{\prime} 24^{\prime \prime} \mathrm{E}, 17-20 . I V .2012$ (A. Kompantsev).

Genitalia examined in all specimens but one female.

DIAGNOSIS. Elytra more or less parallel-sided. Head yellow, with Y-shaped patch; pronotum widely to narrowly black along sides because of yellow paramedian spots being narrow or wide, respectively (Figs 74-76); elytral transverse band narrow and strongly dentate. Female tergite VII with 812 straight apical setae of medium size, sternite VII mostly bisetose in male. Median lobe of aedeagus (Figs 27-28) with apex robust, tapered, widely triangular, pointed, coarsely sculptured except dorsally, i.e., unevenly and rather desely strigose and minutely tuberculate, symmetric or almost so in dorsal view, with a distinct ventro-apical carina. Body of internal sac in lateral view geniculate, angulate dorsobasally; proximal basal bulbs projecting both basad and laterad, distal basal bulb large, oblong, as long as apex of median lobe in dorsal view; the body dorsally and distal basal bulb with 
microtrichia well-developed and dense (Fig. 27 shows membranous apex not everted and thence invisible; no angle between it and the body accordingly).

REDESCRIPTION. Unnecessary here except as follows: Body macropterous or wings dimorphic (brachypterous adults have been found in at least one local population). BL 13.5$18.5 \mathrm{~mm}$ (in specimens examined). Body pattern varying (Figs 74-76). Dorsum glabrous in general, with very short individual setae scattered here and there over elytra; head and pronotum without or with similar setae just behind supraocular seta and/or along base and along apex; sometimes basal and apical pronotal pilosity fairly dense, with setigerous punctures, especially those along base, being usually small and imperceptible.

Pronotum as wide as long, subcordate, broadest just before middle, with sides subsinuate a fifth from base and rounded before; basal angles mostly right or very slightly obtuse, with extreme apices slightly blunted. Base slightly wider than apex. Lateral bead and groove fine yet distinct throughout, sometimes weak in front of basal angles.

Abdomen (Figs 9, 19): Tergite VII with apical setae straight and moderately strong; double punctation dense; larger punctures rather fine and very dense in basal half, becoming coarse and sparser apicad; minute punctures rather few in number. Sternite VIII with hemisternite entirely yet faintly sclerotized, less so medially, and desclerotized mediobasally, with inner apical setae straight or slightly curved. male.

Legs: Profemora in dorsal view conspicuously tumid in

Female gonocoxite IX nearly parallel-sided and slightly curved (Fig. 59). Spermathecal receptacle asymmetric, tumid, slightly Y-shaped, with oner horn nearly absorbed (Fig. 67).

GEOGRAPHIC DISTRIBUTION. This species has long been considered to occur throughout the Oriental region east to, and including, the Papuan region, ranging as far north as eastern China and the Maritime Province. Andrewes [1926] reported S. javanus from Luzon, the Philippines, and Lowerens [1953] from the Lesser Sunda Isles (Sumba, Flores, and Timor). On the other hand, Darlington [1968] deleted $S$. javanus from the Papuan faunal list and Giachino [2005] neither reviewed nor keyed this species for New Guinea, too. Habu [1967, 1984] only reported S. javanus from the Ryukyus and the Satsunan Islands in southernmost Japan (Takara, Amamioshima, and Tokunoshima Is.), and the records of the species in China and the Maritime Province [Lafer, Zolotarenko, 1971; Lafer, 1973] proved to refer to S. agnatus (see below). Andrewes [1929] noted also that he had seen no Indian specimens of $S$. javanus other than one or two from Odisha and Assam. This, combined with no recent records made in India [Venugopal, Thomas, 2019], suggests that $S$.
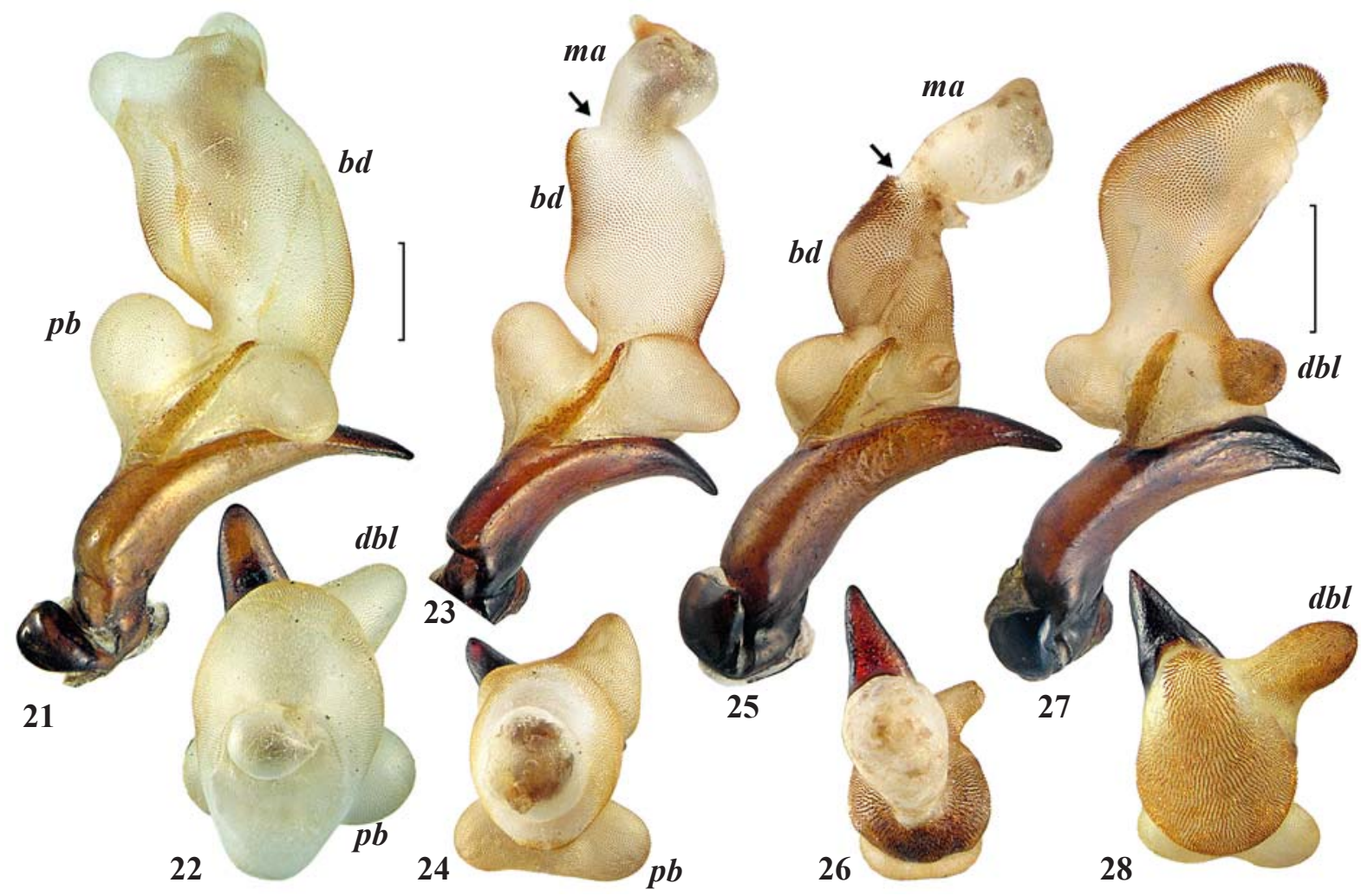

Figs 21-28. Stenaptinus spp., median lobe of aedeagus with everted and inflated internal sac: $21-22-S$. marginicollis; 23-24 - S madagascariensis; 25-26 - S. fumigatus; 27-28 - S. javanus; 21, 23, 25, 27 - left aspect; 22, 24, 26, 28 - dorso-apical aspect; bd body of internal sac; $\boldsymbol{d} \boldsymbol{b} \boldsymbol{l}$ - left distal basal bulb; $\boldsymbol{m} \boldsymbol{a}$ - membranous apex; $\boldsymbol{p} \boldsymbol{b}$ - proximal basal bulb. Scale bars: $1 \mathrm{~mm}$. The arrowhead shows the base of membranous apex, which is conformable to gonopore.

Рис. 21-28. Stenaptinus spp., средняя доля эдеагуса с вывернутым и надутым внутренним мешком: 21-22 - S. marginicollis; 2324 - S. madagascariensis; 25-26 - S. fumigatus; 27-28 - S. javanus; 21, 23, 25, 27 - слева; 22, 24, 26, 28 - дорзо-апикально; bd тело внутреннего мешка; $\boldsymbol{d} \boldsymbol{b}$ - левый дистальный базальный пузырь; $\boldsymbol{m a}$ - мембранозная вершина; $\boldsymbol{p} \boldsymbol{b}$ - проксимальный базальный пузырь. Масштаб: 1 мм. Стрелкой показано основание мембранозной вершины внутреннего мешка, соответствующее гонопору. 
javanus is either rare eastern species in India or absent from there at all. From this one could deduce that the species range extends in Indochina south to the Sunda Isles and east to south China, including Taiwan, easternmost Japan, and probably also the Philippines.

HABITATS AND HABITS. In Indochina, $S$. javanus is less frequent than a similar species, $S$. agnatus. All the specimens taken by me were hand collected on a bog at the edge of a forest in low mountains. The species is also attracted to lights at night.

COMMENTS. The fact that three similar and thence confused species, S. javanus, S. agnatus and S. fimbriatus, have very distinctive aedeagi settles any doubts about species status of the taxa.

\section{Stenaptinus lissoderus (Chaudoir, 1850)}

Figs 2, 12, 29-30, 64, 98-102.

Chaudoir, 1850: 79 (Pheropsophus; 'Thibet'); 1876: 18, 24; Andrewes, 1930: 274; Venugopal et Thomas, 2019: 75. - picicollis Chaudoir, 1876: 44; Bates, 1892: 392; Andrewes, 1930: 275; Venugopal et Thomas, 2019: 79; syn.n. — javanus: Jedlička, 1964: 532 (part.).

MATERIAL. $30^{7} 0^{7}, 2$ (So (SIEE), India, N Goa State, Ashwem Beach Area, 24.I-26.III.2013 (A. Sokolov); 2 specimens (SZM), N Goa, Calangut, near Hotel Vilage Royal, carrion traps, $h=9 \mathrm{~m}$, $15.54^{\circ} \mathrm{N} / 73.77^{\circ} \mathrm{E}, 2-3 . X I .2013$ (V.K. Zinchenko); O $^{7}$ (MSPU), Sri Lanka, Central Province, Peradeniya vill., Botanical Garden, 15.I.1997 (A. Kuznetsov); , same data, except for: Pidura Mt Ridge, Piduratalagala Mt, SSW slope, $2100 \mathrm{~m}$, 20.I.1997; 2 우 (SIEE), N Thailand, Mae Hong Son Province, env. Pai, 19¹4'14"N/ 98 28'55"E, h=600 m, 28-29.IV.2013 (I. Melnik); 1 specimen

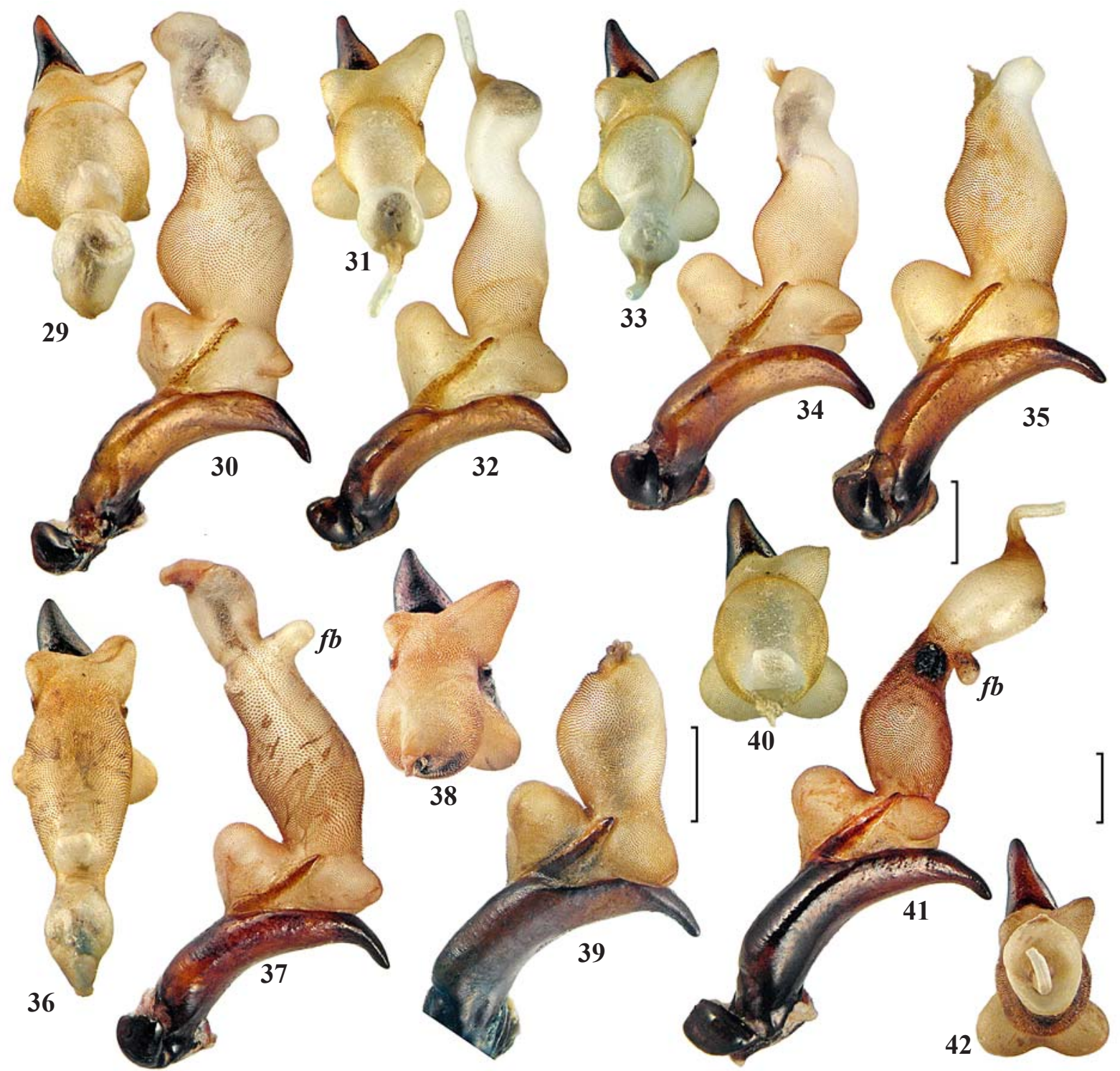

Figs 29-42. Stenaptinus spp., median lobe of aedeagus with everted and inflated internal sac: $29-30-$ S. lissoderus; 31-32 - S. c. consularis; 33-34 - S. c. flaviceps ssp.n.; 35-42 - S. stenoderus from Pu Mat (35, 40), Thailand (36-37), Ramnagar env. (38-39) and Song Thanh (41-42); 29, 31, 33, 36, 38, 40, 42 — dorso-apical aspect; 30, 32, 34-35, 37, 39, 41 — left aspect; fb — preapical frontal bulb. Scale bars: 1 mm.

Рис. 29-42. Stenaptinus spp., средняя доля эдеагуса с вывернутым и надутым внутренним мешком: 29-30-S. lissoderus; 3132 - S. c. consularis; 33-34 - S. c. flaviceps ssp.n.; 35-42-S. stenoderus из Пумата $(35,40)$, Таиланда (36-37), окр. Рамнагара (3839) и Сонгтханя (41-42); 29, 31, 33, 36, 38, 40, 42 - дорзо-апикально; 30, 32, 34-35, 37, 39, 41 - слева; $\boldsymbol{f b}$ - предвершинный фронтальный пузырь. Масштаб: 1 мм. 


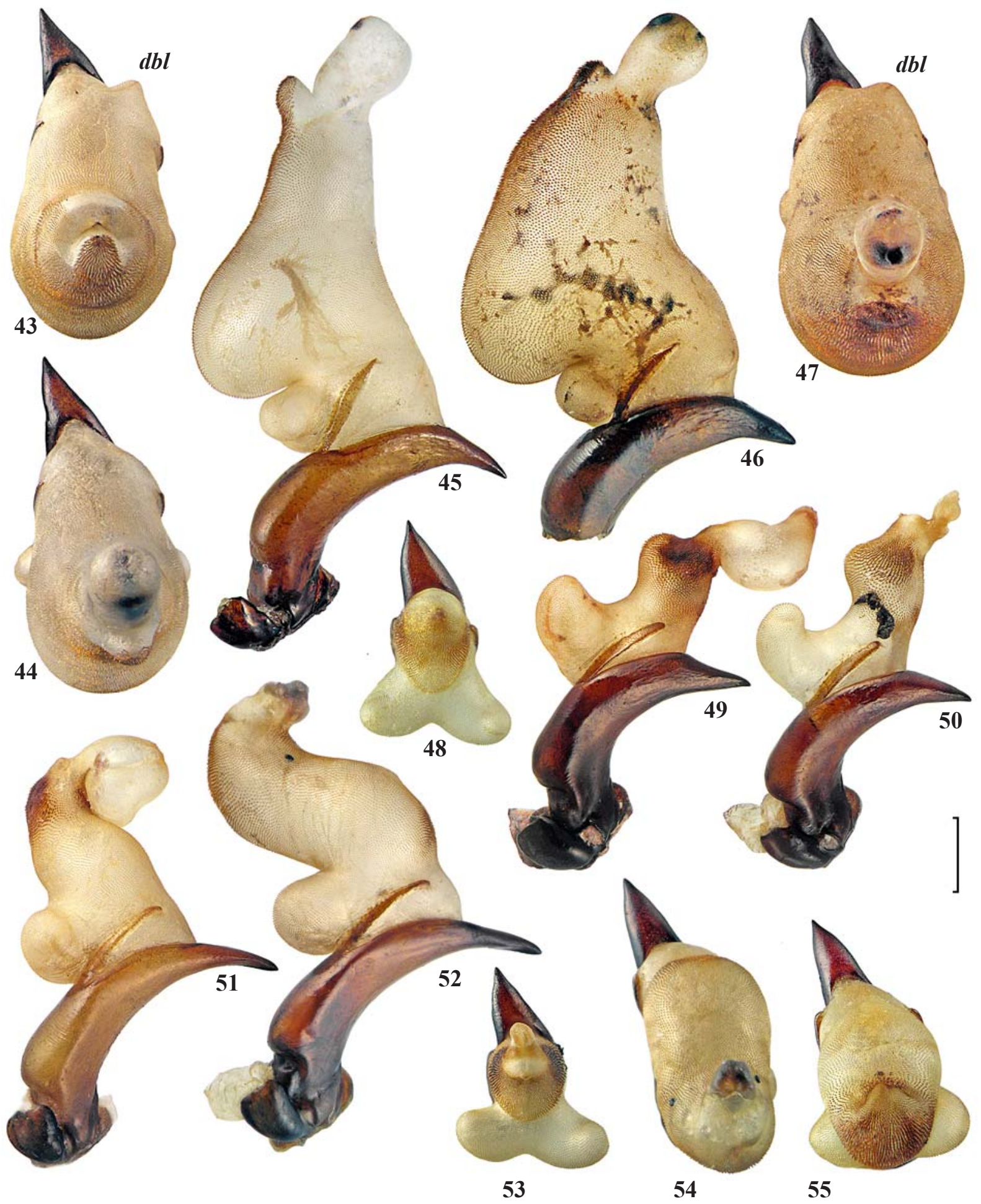

Figs 43-55. Stenaptinus spp., median lobe of aedeagus with everted and inflated internal sac: 43-47 - S. agnatus from Cat Tien (43-45) and Kon Ka Kinh (46-47); 48-50, 53 - S. fimbriatus from Cat Tien (48) and Sumatra (49-50, 53); 51, 55 — S. dongnaiensis sp.n.; 52, 54 - S. sumatrensis sp.n.; 43-44, 47-48, 53-55 - dorso-apical aspect; 45-46, 49-52 — left aspect; $\boldsymbol{d b l}$ — left distal basal bulb. Scale bar: $1 \mathrm{~mm}$.

Рис. 43-55. Stenaptinus spp., средняя доля эдеагуса с вывернутым и надутым внутренним мешком: 43-47 - S. agnatus из Катьена (43-45) и Конкакиня (46-47); 48-50, 53 - S. fimbriatus из Катьена (48) и с Суматры (49-50, 53); 51, 55 - S. dongnaiensis sp.n.; 52, 54 - S. sumatrensis sp.n.; 43-44, 47-48, 53-55 — dorso-apical aspect; 45-46, 49-52 — left aspect; $\boldsymbol{d} \boldsymbol{b l}$ — левый дистальный базальный пузырь. Масштаб: 1 мм. 
(SZM), Nakhon Ratchasima Province (Korat), Saeng Sang, Lam Sae Dam, Tha Plan National Park, h=250 m, $14^{\circ} 16^{\prime} 40^{\prime \prime} \mathrm{N} /$ $102^{\circ} 25^{\prime} 28.5^{\prime \prime} \mathrm{E}, 7-8 . V I .2010$ (A.V. Korshunov).

Genitalia examined in three males and two females.

DIAGNOSIS. A fairly slender species with pronotum uniform red to black; elytra subparallel-sided, black, with a fairly wide transverse median band which is alternatively dentate anteriorly and posteriorly. Head entirely red to black between pronotum and frontoclypeal suture, with supra-antennal plates, sides of neck, and often also distinct to vague subtransverse patch on a level with anterior margin of eye pale. Female tergite VII with 9-12 straight apical setae, sternite VII mostly bisetose in male. Median lobe of aedeagus (Figs 29-30) with apex strongly bent ventrad, pointed, more or less coarsely sculptured ventrally. Internal sac without right distal basal bulb, in lateral view with a preapical frontal bulb.

REDESCRIPTION. BL 15-17.7 mm (in specimens examined). Body pattern as in Figs 98-102: elytron with humeral spot small or medium-sized; transverse median band reaching lateral margin or (mostly) not, more or less strongly dentate, often with teeth blunt or rounded apically; pale lateral margin missing to rather wide, merged into pale apical margin yet not reaching humerus. Head and pronotum glabrous, without or with several individual short setae, with setigerous punctures imperceptible.

Pronotum rather small and short, as wide as or barely wider than long, subcordate, broadest two fifths from apex, with sides subsinuate a fifth from base and rounded before; basal angles nearly right, with extreme apices blunted. Base slightly wider than apex. Lateral bead and groove distinct throughout.

Abdomen (Figs 2, 12): Tergite VII punctate as in $S$. javanus, larger punctures being sparser, finer and unevenly spaced in some males.

Internal sac of aedeagus (Figs 29-30) in lateral view has body straight, with microtrichia moderately developed over the body which is incrassate medially and thence slightly separated from proximal basal bulbs; these in anterodorsal view more or less projecting laterad; left distal basal bulb only present; it is triangular, about as large as apex of median lobe in dorsal view.

Female gonocoxite IX (Fig. 64) and reproductive tract as for S. javanus.

GEOGRAPHIC DISTRIBUTION. Throughout Hindustan (including Sri Lanka, Pakistan, Nepal, and Bhutan) and western Indochina east to Laos and south to the Malay Peninsula. The record of the species in Laos [Andrewes, 1930] makes its occurrence not improbable in central or northern Vietnam.

HABITATS AND HABITS. No exact data.

COMMENTS. According to the descriptions, S. lissoderus is distinctive from $S$. picicollis in only having the head and pronotum entirely pale ( $v s$. infuscated). My comparison of the holotype of $S$. lissoderus and a syntype of $S$. picicollis from Siam, as depicted in Venugopal and Thomas [2019: Figs 2A and $2 \mathrm{C}$, respectively] with both each other and the specimens listed above has revealed no differences except in body colour. Because diferently coloured males from one and the same population as well as from different populations have similar aedeagi, the two names are here considered as conspecific and only referred to as different colour morphs, either pale (forma 'lissodera') or melanistic (forma 'picicollis').

\section{Stenaptinus consularis (Schmidt-Göbel, 1846)}

Figs 5, 8, 15, 18, 31-34, 57, 60, 90-94.

DIAGNOSIS. Elytra slightly wider apically than basally, with humeri more or less widely rounded and rather distinct. Dorsal pattern (Figs 90-94): black patch on vertex small Vshaped, narrow to missing; pronotum black, with yellowish spots narrow and separate, to yellow, with base, apex and lateral beads black; elytral transverse band from narrow, more or less dentate, isolated from lateral margin, to wide and laterally extended to widely pale apical margin. Tergite VII with 9-14 strong and straight apical setae in female, sternite VII bi- to quadrisetose in male. Aedeagus (Figs 31-34) similar to that of $S$. lissoderus, except that apex of median lobe is blunt and the internal sac has larger basal bulbs: proximal bulbs and left distal bulb being very large, and right distal bulb rudimentary yet very distinct (vs. missing). Female gonocoxite IX (Fig. 57, 60 ) and reproductive tract as in $S$. lissoderus.

GEOGRAPHIC DISTRIBUTION. Northern India and northern Indochina, including Myanmar and Thailand east to northern and central Vietnam. The species range is similar to that of S. stenoderus yet not quite clear, since confusion of the two species occurred based on Chaudoir's [Chaudoir, 1876] supposion of their synonymy. Bates [1892] shared and Andrewes then [Andrewes, 1923, 1924] confirmed this supposition, while the latter author occasionally used the junior synonym for the species [Andrewes, 1924].

COMMENTS. The adults from all examined Vietnamese populations of the species are constantly different from the other ones in body shape, proportions, and colour pattern, the latter being almost invariable, which is largely uncharacteristic of the genus. This seems to me sufficient to describe a new subspecies.

\section{3a. Stenaptinus consularis consularis}

(Schmidt-Göbel, 1846)

Figs 5, 15, 31-32, 60, 90-92.

Schmidt-Göbel, 1846: 75 (Brachinus; 'Birma'); Bates, 1892: 392 (Pheropsophus); Andrewes, 1923: 44; 1924: 116 (part.); 1930: 272; Jedlička, 1964: 532; Hrdlička, 2017: 479; Venugopal et Thomas, 2019: 69, 72. — stenoderus Andrewes, 1924: 56 (part.).

MATERIAL. Digital image of a syntype (Venugopal et Thomas, 2019: 69, Fig. 1G).

Additional material. $3 \sigma^{\top} \sigma^{\top}, 2 \circ 0$ (SIEE), N Thailand, Mae Hong Son Province, env. Pai, $19^{\circ} 22^{\prime}$ N/ 98 $30^{\prime} 29^{\prime \prime}$ E or $19^{\circ} 21^{\prime} 48^{\prime \prime} /$ $98^{\circ} 27^{\prime} 57^{\prime \prime} \mathrm{E}$, or $19^{\circ} 21^{\prime} 41^{\prime \prime} / 98^{\circ} 27^{\prime} 46^{\prime \prime} \mathrm{E}, \mathrm{h} \sim 600 \mathrm{~m}, 27 . \mathrm{IV}-9 . V .2013$ (I. Melnik \& O. Mosalov), including $\mathrm{O}^{7}+$ taken at light. Genitalia examined in three males and one female.

REDESCRIPTION. Body. BL 14-19 mm. Body pattern as in Figs 90-92: head yellow except narrow to missing black $\mathrm{V}$-shaped patch on vertex; dorsal yellow pattern otherwise consisting of narrow paramedian spots on pronotum, and elytral markings, such as small to missing humeral spot, mostly narrow median fascia isolated from lateral margin, ridges apically, and sometimes also spot in outer angles.

Head and pronotum totally impunctate and glabrous (except for imperceptible yet rather dense microscopic ciliae).

Pronotum quadrate, somewhat subcordate, barely longer than wide, PW/PL 0.92-1.0 (0.97), narrow, PW/HW 0.961.01 (0.98), broadest a third from apex, PLw/PW 0.31-0.38 (0.34); sides barely to distinctly sinuate a fifth from base and rounded in front. Base slightly wider than apex, PB/PA 1.061.12 (1.08), with basal and apical margins gently convex or gently concave, respecrively, the former with subtle or no sinuation towards basal angles; these very slightly acute to right and rather sharp. Lateral bead and groove very fine and mostly obliterate in basal fourth.

Elytra rather short, EL/EW 1.44-1.53 (1.48), EW/EL 1.98-

2.08 (2.04), similar in shape and proportions in both sexes.

Sternite VII mostly quadrisetose in male.

GEOGRAPHIC DISTRIBUTION. Major part of the species range, except for northern and central Vietnam.

HABITATS AND HABITS. No data except that adults flight to light at night. 
3a. Stenaptinus consularis flaviceps Fedorenko, ssp.n.

Figs 8, 18, 33-34, 57, 71, 93-94.

MATERIAL. Holotype $\sigma^{7}$ (ZMMU) and paratypes (SIEE): $10 \sigma^{7} \sigma^{7}, 15$ 우 labelled 'Vietnam, Kon Tum Prov[ince]., Kon Plong Distr., $14^{\circ} 43^{\prime} \mathrm{N} / 108^{\circ} 19^{\prime} \mathrm{E}$, Dak Khe River, $\mathrm{h}=1030 \mathrm{~m}, 8$ - 23.IV.2015, D.Fedorenko leg.'; Paratypes: $\sigma^{7}$, same data except 4-12.VI.2016; $\sigma^{7}$, 'Vietnam, Nghe An Prov., 109 km WNW of Vinh, Pu Mat Nature Reserve, $18^{\circ} 57^{\prime} 22^{\prime \prime} \mathrm{N} / 104^{\circ} 41^{\prime} 05^{\prime \prime} \mathrm{E}, \mathrm{h} \sim 200 \mathrm{~m}, 11-$ 25.IV.2018, A.Abramov leg,'; O 'Vietnam, Ha Tinh Prov., Ke Go Nature Reserve, $18^{\circ} 06^{\prime} 30^{\prime \prime} \mathrm{N} / 1^{\circ} 106^{\circ} 01^{\prime}, \mathrm{h}=40 \mathrm{~m}, 7-14 . V .2015$, A.Abramov leg.'; Paratype + , (MSPU), 'Vietnam, C[entral]. An- nam, prov. Quan[g] Binh, Minh Hoa [= Quy Dat] distr., Ke Bang [National Park] env. Yen Hop, 16.IV.1999, leg. S. Kruskop'.

Additional material (SIEE): $0^{7}+9$ labelled 'Gia Lai Province, $\sim 55$ km ENE of Pleiku, $14^{\circ} 17^{\prime} 24^{\prime \prime} \mathrm{N} / 108^{\circ} 27^{\prime} 47^{\prime \prime} \mathrm{E}, \mathrm{h}=570 \mathrm{~m}$, dak Lar Pa River, riverbank, 8-20.V.2017, D. Fedorenko leg.'.

Genitalia examined in ten males and one female.

DIAGNOSIS. See the key and description below.

DESCRIPTION. As for the nominotypical subspecies except the following: BL 15.6-19 $\mathrm{mm}$. Dorsal pale pattern extensive (Figs 71, 93-94): entire head yellow, occasionally with a vague black V-shaped patch; pronotum yellow except base, apex and lateral margins; elytral humeral spot larger, elytral median fascia wide, reaching lateral margin, extended

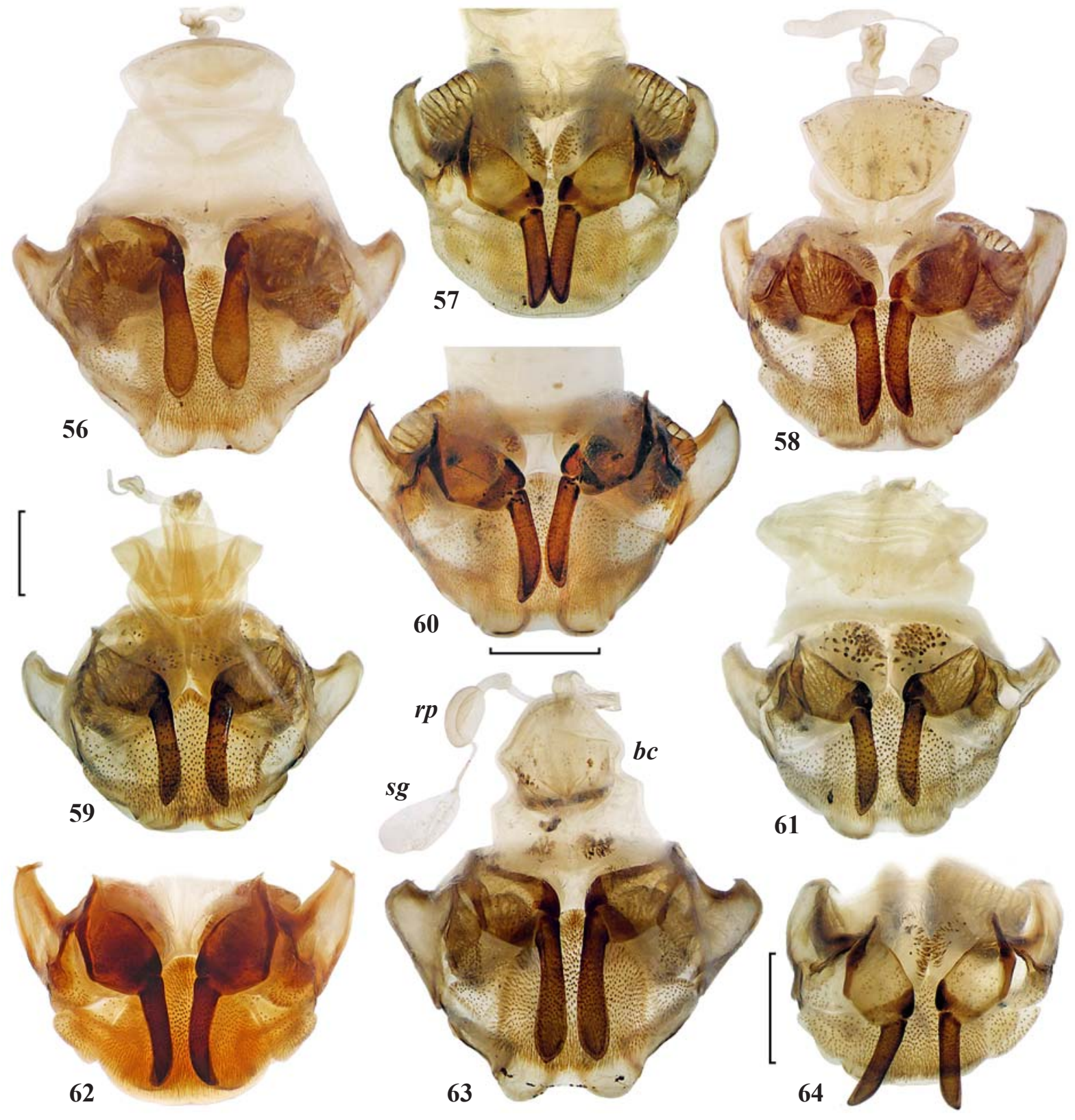

Figs 56-64. Stenaptinus spp., urite IX in female, ventral aspect: 56 - S. sumatrensis sp.n.; 57 - S. consularis flaviceps ssp.n. from Gia Lai Prov.; 58 - S. stenoderus; 59 - S. javanus; $60-$ S. c. consularis; $61-$ S. agnatus; 62 - S. marginicollis; 63 - S. fimbriatus; $64-$ S. lissoderus; $\boldsymbol{b} \boldsymbol{c}$ - bursa copulatrix; $\boldsymbol{r} \boldsymbol{p}$ - spermathecal receptacle; $\boldsymbol{s} \boldsymbol{g}$ - spermathecal gland. Scale bars: $1 \mathrm{~mm}$.

Рис. 56-64. Stenaptinus spp., урит IX самки вентрально: 56 - S. sumatrensis sp.n.; 57 - S. consularis flaviceps ssp.n. from Gia Lai Prov.; 58 - S. stenoderus; 59 - S. javanus; $60-$ S. c. consularis; $61-$ S. agnatus; $62-$ S. marginicollis; $63-$ S. fimbriatus; $64-S$. lissoderus; $\boldsymbol{b} \boldsymbol{c}$ - копулятивная сумка; $\boldsymbol{r} \boldsymbol{p}$ - семеприемник сперматеки; $\boldsymbol{s} \boldsymbol{g}$ - железа сперматеки. Масштаб: 1 мм. 
along side to a widely pale apical margin and also slightly basad, with lateral margin pale pale or narrowly infuscated in apical half. Sometimes 1-2 setules behind supra-ocular seta.

Pronotum barely wider, PW/PL 0.94-1.03 (1.0), and slightly larger, PW/HW 1.02-1.10 (1.05), broadest a third from apex, PLw/PW 0.27-0.41 (0.34); sides subsinuate a fifth from base. Base wider, PB/PA 1.08-1.15 (1.12), basal angles mostly very slightly obtuse and blunt.

Elytra long,EL/EW 1.52-1.66(1.59), EW/EL 1.56-2.08(1.87).

Sternite VII mostly bisetose, sometimes trisetose, in male. GEOGRAPHIC DISTRIBUTION. Northern and Central Vietnam from Nghe An to Kon Tum and Gia Lai provinces.

NAME. Refers to the entirely pale head as a distinctive feature of the new subspecies.

HABITATS AND HABITS. Of the specimens taken by the author, most were hand collected by floodland pools (often together with specimens of $S$. agnatus) and the other few on river banks. In the Kon Plong District, the adults were found to be frequent in close vicinity to a light-trap, but no specimen was attracted to the light.

COMMENTS. Two specimens, male and female, from Gia Lai Province belong to the new subspecies and match well the diagnosis, except that the former has color pattern more similar to that of the nominotypical subspecies. Hence the two specimens are not included in the type series.

At least two of totally three specimens mentioned in the description of Pheropsophus javanus v. ruficeps Jedlička, 1964, nom. nud. [Jedlička, 1964: 532], one from Laos and the other from central Vietnam, belong to this new subspecies rather than to any other species.
4. Stenaptinus stenoderus (Chaudoir, 1850), sp.bon.

Figs 1, 11, 35-42, 58, 65, 96-97, 103-105.

Chaudoir, 1850: 77 (Pheropsophus; 'Nord de 1'Hindostan'); 1876: 18, 41 ('Présidence du Bengale'). — consularis (part.): Andrewes, 1923: 44; 1924: 56, 116; 1930: 272; Jedlička, 1964: 532; Hrdlička, 2017: 479; Venugopal et Thomas, 2019: 72. — lei Hrdlička, 2019: 82 (Tay Giang, Central Vietnam), syn.n. - snizeki Hrdlička, 2019: 83 (Chiang Dao, Northern Thailand), syn.n. — ? kuntzeni Dupuis, 1914: 29 (Kosempo, Taiwan).

MATERIAL. Two female specimens (MNHN, digital images) in the box with a handwritten label 'stenoderus/ Chaud/ Indes or. boréale/ $\mathrm{C}^{\mathrm{t}}$ Boys.' at its bottom. Of them, the specimen with labels 'Ex Musaeo/ Chaudoir' and 'G. J. Arrow/ vidit 1901' is certain to be the holotype, and another specimen without head bears the only label 'Ex Musaeo/ Chaudoir'.

Additional material. 1ㅇ (SIEE), Northern India, Uttarakhand State, Haridwar Distr., env. Chilla, Ganges, floodland forest, $29^{\circ} 58^{\prime} \mathrm{N} /$ 78 $12-13^{\prime} \mathrm{E}, \mathrm{h}=330 \mathrm{~m}, 14-16$. IV.2012 (I. Melnik); $0^{7}$ (SIEE), same locality, except for $8 \mathrm{~km}$ NNE of Ramnagar, Pipaliasot river valley, $29^{\circ} 28.5^{\prime} \mathrm{N} / 79^{\circ} 10^{\prime} \mathrm{E}, \mathrm{h}=420 \mathrm{~m}, 20 . I V .2012$ (E. Ivanov); $0^{7}+$ (SIEE), $^{\circ}$

N Thailand, Mae Hong Son Province, env. Pai, $19^{\circ} 22^{\prime}$ N $/ 98^{\circ} 30^{\prime} 29^{\prime \prime} \mathrm{E}$, $\mathrm{h}=600 \mathrm{~m}, 27 . \mathrm{IV}-9 . \mathrm{V} .2013$ (I. Melnik); $2 \mathrm{O}^{\top} \mathrm{O}^{\top}, 2$, 우 (SIEE), Vietnam, Nghe An Province, $109 \mathrm{~km}$ WNW of Vinh, Pu Mat Nature Reserve, $18^{\circ} 57^{\prime} 22^{\prime \prime} \mathrm{N} / 104^{\circ} 41^{\prime} 05^{\prime \prime} \mathrm{E}, \mathrm{h}=270 \mathrm{~m}, 11-25 . I V .2018$ (A. Abramov); $\mathrm{O}^{7}$ (ZISP), mountains W of Quy Chau, $\mathrm{h}=600 \mathrm{~m}$, 8.III.1962 (O.N. Kabakov); 2 우 (ZISP), same data, except for: mountains SW of Quy Chau, h=400 m, 13.II.1963; O (MSPU), Quang Binh Province, Minh Hoa [=Quy Dat] Distr., env. Yen Hop, Ke Bang National Park, 2430.III.1999 (S. Kruskop); $50^{\top} 0^{\top}, 9$ 우 (SIEE), Quang Nam Province, Nam Giang Distr., Song Thanh National Park, 15 $33^{\prime} 48^{\prime \prime}$ N/ $107^{\circ} 23^{\prime} 22^{\prime \prime} \mathrm{E}, \mathrm{h}=1050 \mathrm{~m}, 23 . \mathrm{IV}-11 . \mathrm{V} .2019$ (D. Fedorenko); 3 우 (ZISP), Thai Nguen Province NW of Tam Dao [Son Zuong] Mt ridge, h=200-300 m, 23.II.1962 (O.N. Kabakov).
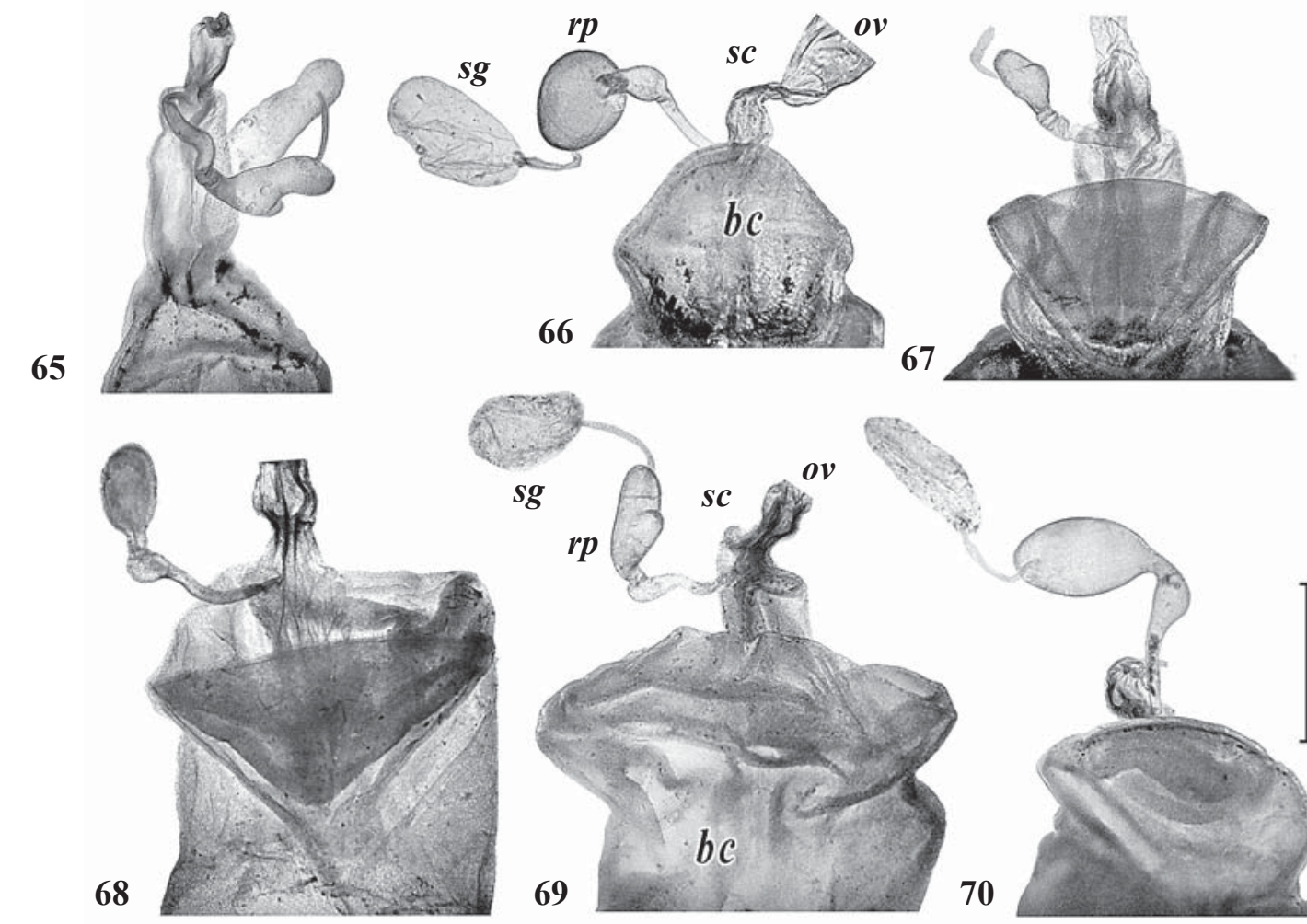

Figs 65-70. Stenaptinus spp., female reproductive tract: $65-$ S. stenoderus; $66-$ S. fimbriatus; $67-$ S. javanus; $68-$ S. marginicollis; 69 - S. agnatus; 70 - sumatrensis sp.n.; $\boldsymbol{b} \boldsymbol{c}$ — bursa copulatrix; $\boldsymbol{o} \boldsymbol{v}$ - common oviduct; $\boldsymbol{r} \boldsymbol{p}$ - spermathecal receptacle; sc — seminal canal; sg - spermathecal gland. Scale bar: $1 \mathrm{~mm}$.

Рис. 65-70. Stenaptinus spp., репродуктивный тракт самки: $65-$ S. stenoderus; $66-$ S. fimbriatus; $67-$ S. javanus; $68-$ S. marginicollis; 69 - S. agnatus; 70 - sumatrensis sp.n.; bc - копулятивная сумка; ov - непарный яйцевод; $\boldsymbol{r p}$ - семеприемник сперматеки; $\boldsymbol{s} \boldsymbol{a}$ - апикальные щетинки; $\boldsymbol{s} \boldsymbol{c}$ - семенной канал; $\boldsymbol{s} \boldsymbol{g}$ - железа сперматеки. Масштаб: 1 мм. 
Genitalia examined in eight males and four females.

DIAGNOSIS. An apterous species with elytra lacking humeri and thence much wider apically than basally in most populations. Dorsal pattern (Figs 96-97, 103-105): vertex with black patch large Y-shaped to small pentagonal yet mostly retaining anterior horns; pronotal pale spots separate, small and/or narrow, to large and fused, leaving lateral margins widely black; elytral transverse band not reaching lateral margin, mostly large and indistinctly dentate or edentate. Tergite VII with 9-15 strong and straight apical setae in female, sternite VII varying from asetose to quadrisetose in male. Aedeagus similar to that of S. lissoderus (Figs 35-42), except for its apex blunt and the internal sac with proximal basal bulbs larger.

Slender specimens are very similar to those of $S$. javanus, except that the elytral transvere median band is wide, slightly dentate, and isolated from lateral margin, and the wings are constantly missing or much reduced in the former.

REDESCRIPTION. Body. BL 10.5-22 mm. Body pattern (Figs 96-97, 103-105): elytra with apical margin not or narrowly pale; femoral apices black (at least laterally), tibiae infuscated laterally in some populations. Head and pronotum glabrous, without or with several individual short setae, yet setigerous punctures imperceptible.

Pronotum subcordate, slightly to indistinctly longer than wide, broadest a third from apex, with sides barely to distinctly sinuate a fifth from base and rounded before; basal angles slightly obtuse to slightly acute, rather sharp to blunt. Base barely wider than apex. Lateral bead and groove entire and very distinct in Vietnamese populations to fine and entire or imperceptible in front of basal angles nearly imperceptible in the other ones.

Elytra similar in shape and proportions in males and females.

Abdomen (Figs 1, 11): Tergite VII with larger punctures coarse and dense in female, slightly finer and often also sparser and unevenly spaced in males. Sternite VIII with lateral apical setae rather strongly curved in female.

Legs: Profemora tumid in male.

Female genitalia and reproductive tract (Figs 58, 65) similar to those of $S$. javanus.

GEOGRAPHIC DISTRIBUTION. As for S. consularis. The fact is worthy of note that Chaudoir [1876] translated 'Nord de 1'Hindostan' as the original type locality of the species into 'présidence du Bengale' and provided two additional records, including 'Deccan' meaning Dacca in fact.

HABITATS AND HABITS. This species has forestdwelling habits, being generally confined to $200-600 \mathrm{~m}$ altitudes in piedmonts, with three local populations found at 1050-1400 $\mathrm{m}$ in Central Vietnam. This species often live syntopically with some other species of the group, such as $S$. consularis (in the $\mathrm{Pu}$ Mat Nature Reserve and the Ke Bang National Park in Vietnam, and also in the environs of Pai, Thailand) or S. agnatus (in the Song Thanh National Park).

COMMENTS. This species is incapable of flight because of constantly apterous condition of the adults. Since flight function lost the elytra has become much more variable in shape than in macropterous species, resulting in wider ranges of the ratios EL/EW and EW/PW (Table).

Another result is that local populations of $S$. stenoderus tend to be more isolated from one another than in species having full or polymorhic wings and interpopulation variability tends to surpass intrapopulation variability accordingly. Specifically, the elytra seems to be more dilated apically in populations from Indochina than in those from India. In Thailand and northern Vietnam, the adults have the elytra short, with median fascia not seldom narrow and strongly dentate. Black colour on the head and pronotum becomes considerably reduced in size in populations from Nghe An Province. The adults from there have the Y-shaped patch on vertex shortened from behind and transformed into a pentagon, which is somewhat stellate due to the angles slightly projecting, and pronotum pale, except for its base, apex and narrow lateral margins.

The recently described $S$. lei is distinctive in only having a generally larger body, the pronotum with sides more sinuate in front of base and thence with basal angles rather acute, and the elytral median facia wide and not or only slightly dentate. All these characters have been observed in some other populations of S. stenoderus, therefore $S$. lei is here considered as a group of southern populations of S. stenoderus in Vietnam.

Stenaptinus stenoderus and S. lissoderus may be more closely related to each other than to S. stenoderus because aedeagi of the former two are more similar in having preapical frontal bulb of the internal sac (vs. having no this bulb in $S$. consularis).

\section{Stenaptinus agnatus (Chaudoir, 1876), stat.rest.} Figs 3, 6, 13, 16, 43-47, 61, 69, 82-89.

Chaudoir, 1876: 43 (Pheropsophus; 'Tchusan' [= Zhoushan Is., Zhejiang], China); Bates, 1889: 281 (javanus var.?); 1892: 392; Dupuis, 1913: 419. - javanus (part.): Andrewes, 1930: 273; Csiki, 1933: 1601; Jedlička, 1964: 534; Habu, 1967: 291; 1984: 123; Lafer et Zolotarenko, 1971: 64; Lafer, 1973: 852; Hrdlička, 2017: 480; Venugopal et Thomas, 2019: 73. - worthingtoni Hrdlička, 2019: 85 (Pheropsophus; Khao Soi Dao NP, Thailand), syn.n. - suensoni Schauberger, 1923: 53 (Pheropsophus; Hangchow [Handzhou, Zhejiang] et Kiukiang [Jiujiang, Jiangxi]), syn.n. — ? chinensis Jedlička, 1964: 529, 556 (Pheropsophus; 'China: Thieme').

MATERIAL. Holotype $\sigma^{7}$ (MNHN, digital images) with two labels, 'Ex Musaeo/ Chaudoir' and 'G. J. Arrow/ vidit 1901', and a hanwritten label 'agnatus/ Chaudoir/ Chine/ Tchusan Melly.' at bottom of the box with the holotype.

Additional material (SIEE): $60^{\top} \sigma^{\top},+$, Vietnam, Dongnai Province, Cat Tien National Park, $11^{\circ} 25^{\prime} 18^{\prime \prime} \mathrm{N} / 107^{\circ} 25^{\prime} 44^{\prime \prime} \mathrm{E}$, at light HQL-450, 21.X.-5.XII.2004, $90^{7}, 22$.V. and 15.VI.2005 (D. Fe-

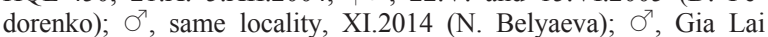
Province, $40 \mathrm{~km}$ ENE of Pleiku, $14^{\circ} 12^{\prime} 11^{\prime \prime} \mathrm{N} / 108^{\circ} 18^{\prime} 54^{\prime \prime} \mathrm{E}$, Kon Ka Kinh National Park, h=890 m, 9-22.V.2016 (D. Fedorenko); $30^{\top} \sigma^{\top}$, Kon Tum Province, Kon Plong Distr., $14^{\circ} 43^{\prime} \mathrm{N} / 108^{\circ} 19^{\prime} \mathrm{E}$, Dak Khe River, h=1030 m, 8-23.IV.2015 (D. Fedorenko); $\sigma^{7}$, same data, except for " on sandy riverbank, 4-12.VI.2016; 20 $\sigma^{7} \sigma^{7}$, $6 \circ 0$, Quang Nam Province, Nam Giang Distr., Song Thanh National

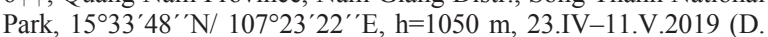
Fedorenko); $\sigma^{\prime}$, same data except 'at light'; 3ㅇ, Ninh Binh Province, $7.5 \mathrm{~km} \mathrm{SSW}$ of Nho Quan, 20 $15^{\prime} 08^{\prime \prime} \mathrm{N} / 105^{\circ} 44^{\prime} 09^{\prime \prime} \mathrm{E}, \mathrm{h} \sim 100 \mathrm{~m}$, at light, 1-5.V.2019 (A. Prosvirov); $+60 \mathrm{~km}$ WSW of Hanoi, Hoa Binh, 10.XII.1988 (N. Belyaeva); 9 , Cambodia, Kratie Province, 7 km S of Kratie, Mekong River (A. Kompantsev); +, (ZSM), Thailand, Nakhon Ratchasima (Korat) Province, La Lu National Park, h=120 m, light trap, $14^{\circ} 28^{\prime} \mathrm{N} / 102^{\circ} 39^{\prime} \mathrm{E}, 9-12$.VIII.2012 (A.V. Korshunov).

Genitalia examined in 15 males and three females.

Besides, digital images of four specimens: 2 우 (EASC), with two handwritten labels: 'Southern Maritime Province, Mt. Kh asan, Golubiny Utyos, VII-VIII.1970, Lafer G.' [in Russian] and 'Pheropsophus javanus Dej., G. Lafer det. 1970'; O' (EASC), same labels except that the date is '1972' on both; $\sigma^{7}$ (http://www.zin.ru), same data.

DIAGNOSIS. Elytra subparallel-sided, with distinct humeri. Dorsal pale pattern mostly well-developed, with elytral transverse band wide and pronotal lateral margins only narrowly infuscated; vertex with Y- or V-shaped patch. Tergite VII with 7-12 strong and straight apical setae in female. Aedeagus distinctive (Figs 43-47): median lobe in dorsal view with apex long, triangular and very pointed; 
internal sac symmetrical or almost so, with body strongly tumid basally and contiguous to proximal basal bulbs; left distal basal bulb missing or vestigial.

Melanistic specimens are hard to discriminate from specimens of $S$. javanus using non-genitalic characters.

REDESCRIPTION. Very similar to $S$. javanus in body shape and proportions (Table). BL 13-21.3 mm. Body pattern (Figs 82-89) highly variable, ranging from similar to that of $S$. javanus, except only that pale elytral transverse band is generally wider and less dentate, to entirely pale. Head glabrous or with a few short setae behind supra-ocular seta, pronotum with no or sparse and very short yet rather distinct pilosity, and punctures being rather large at apex and less distinct at base.

Pronotum quadrate, as long as wide, broadest two fifths from apex, with sides subsinuate a fifth from base and rounded before. Base slightly wider than apex; basal angles mostly slightly obtuse, with extreme apices blunt. Lateral bead and groove very fine, entire or obliterate in front of basal angles.

Abdomen (Figs 3, 6): Tergite VII coarsely and more or less densely punctate, with dense and distinct fine punctures between coarse ones. Sternite VIII with apical setae slightly curved in female.

Female genitalia and reproductive tract (Figs 61, 69) similar to those of $S$. javanus.

GEOGRAPHIC DISTRIBUTION. Eastern and southern China, including Taiwan, as far north as Maritime Province (Russian Far Est); Indochina (Myanmar, Thailand, Cambodia, Vietnam). The distribution pattern of $S$. agnatus otherwise is largely obscured by its confusion with $S$. javanus and $S$. fimbriatus.

HABITATS AND HABITS. This species is common in Indochina. It inhabits manifold open places at 50-1050 m altitudes, while sharing these habitats with $S$. stenoderus or S. consularis flaviceps ssp.n. in some localities explored. The adults flights to light at night, often being collected together with those of other sympatric congeners, such as $S$. fimbriatus, S. dongnaiensis sp.n. and S. tripustulatus (Fabricius, 1792).

COMMENTS. Schauberger [1923] described S. suensoni as a species distinctive from $S$. marginicollis and $S$. jessoensis (Morawitz, 1862), but he did not compared it with S. agnatus, another species known from China long before and, according to the original description, having no difference from $S$. suensoni. A smaller body, $13 \mathrm{~mm}$ in length, in couple with the entirely pale forebody, only differentiates the next Chinese species, $S$. chinensis, from $S$. agnatus. Because the two characters are observed in $S$. agnatus as well, the synonymy $S$. chinensis $=S$. agnatus is not improbable, too. The name 'Thieme' ('China: Thieme') from the description of $S$. chinensis seems to be patronymic Dutch, that of probable collector of the species, and the fact that a certain steersman Thieme has been mentioned by Kuiper [2016] relative to the island of Amoy in the 19th century is what may argue for the surmise. If true, the holotype of $S$. chinensis originated either from the environs of Xiamen or another treaty port in China, e.g., Shanghai, Ningbo, Fuzhou, or Guangzhou.
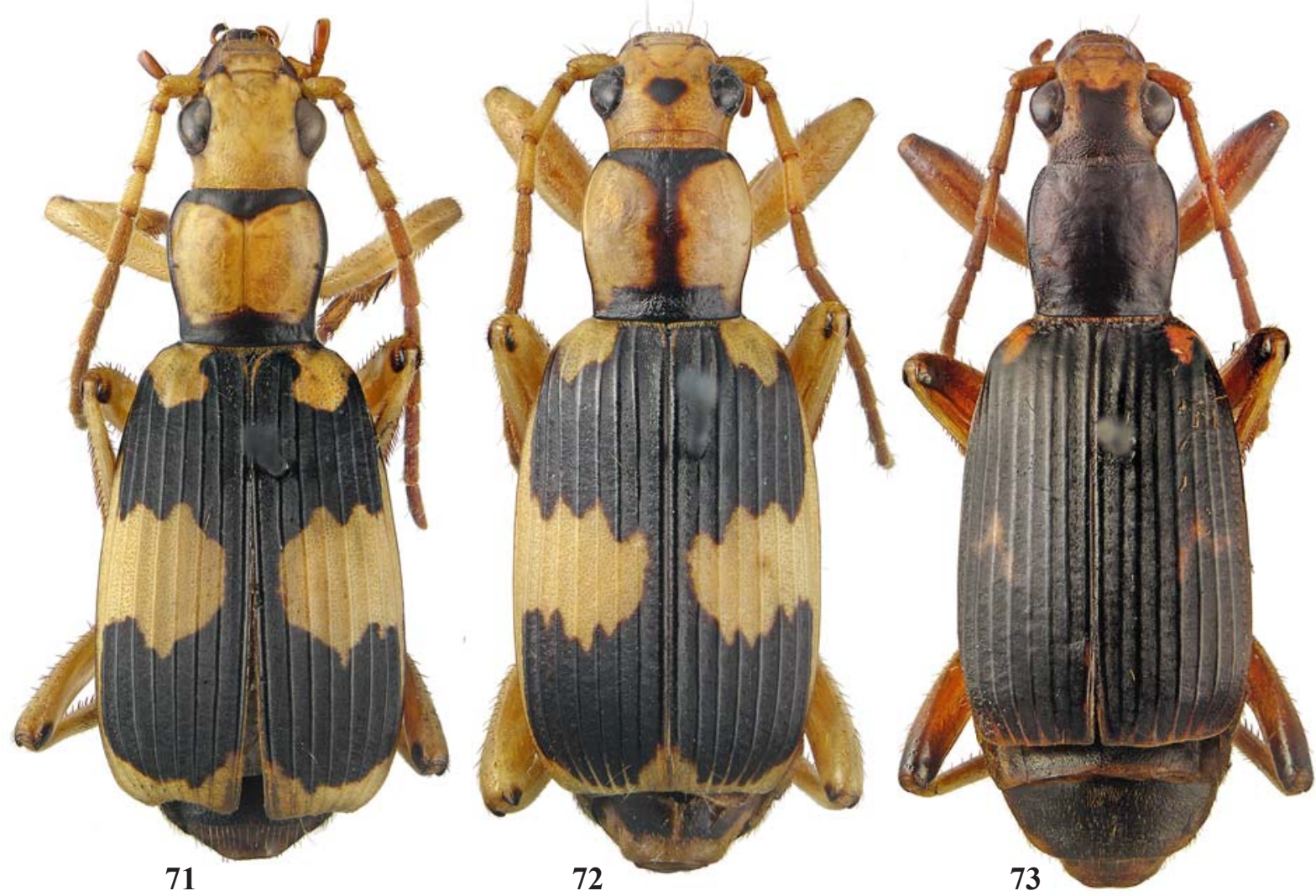

Figs 71-73. Stenaptinus spp., dorsal habitus: $71-$ S. consularis flaviceps ssp.n., female, paratype; $72-$ S. dongnaiensis sp.n., paratype; 73 - S. sumatrensis sp.n., holotype.

Рис. 71-73. Stenaptinus spp., габитус дорзально: $71-$ S. consularis flaviceps ssp.n., паратип, самка; 72 - S. dongnaiensis sp.n., паратип; 73 - S. sumatrensis sp.n., голотип. 
Lafer [Lafer, Zolotarenko, 1971; Lafer, 1973] reported 'S. javanus' from the southernmost Maritime Province based on several male and female specimens, redescribed the species at his hand in details and then [Lafer, 1989] illustrated it by the line drawing of S. javanus from Habu [1967: P1.27, Fig.3; 1984: Fig.179]. My comparison of the digital images of four specimens of $S$. javanus: Lafer, 1971 reveals that all of them belong to $S$. agnatus only. This suggests that most if not all records of $S$. javanus in mainland East Asia should be referred to as $S$. agnatus.
6. Stenaptinus fimbriatus (Chaudoir, 1876), stat.rest. Figs 7, 17, 48-50, 53, 63, 66, 77-81.

Chaudoir, 1876: 43 (Pheropsophus javanus var.; 'côte de Malabar, Siam, Java'). — javanus (part.): Andrewes, 1930: 273; Csiki, 1933: 1601; Jedlička, 1964: 534; Habu, 1967: 291; 1984: 123; Hrdlička, 2017: 480; Venugopal et Thomas, 2019: 73.

MATERIAL. Lectotype + (designated here) (MNHN; digital images) with a yellow hanwritten label 'javanus. $\mathrm{m} / \mathrm{h}[\mathrm{abite}]$. in inf] erior]. Java', two labels 'Ex Musaeo/ Chaudoir' and 'G. J. Arrow/vidit 1901', and a hanwritten label 'javanus Dejean/ Java/ C. Dejean' at bottom of the box with the lectotype.
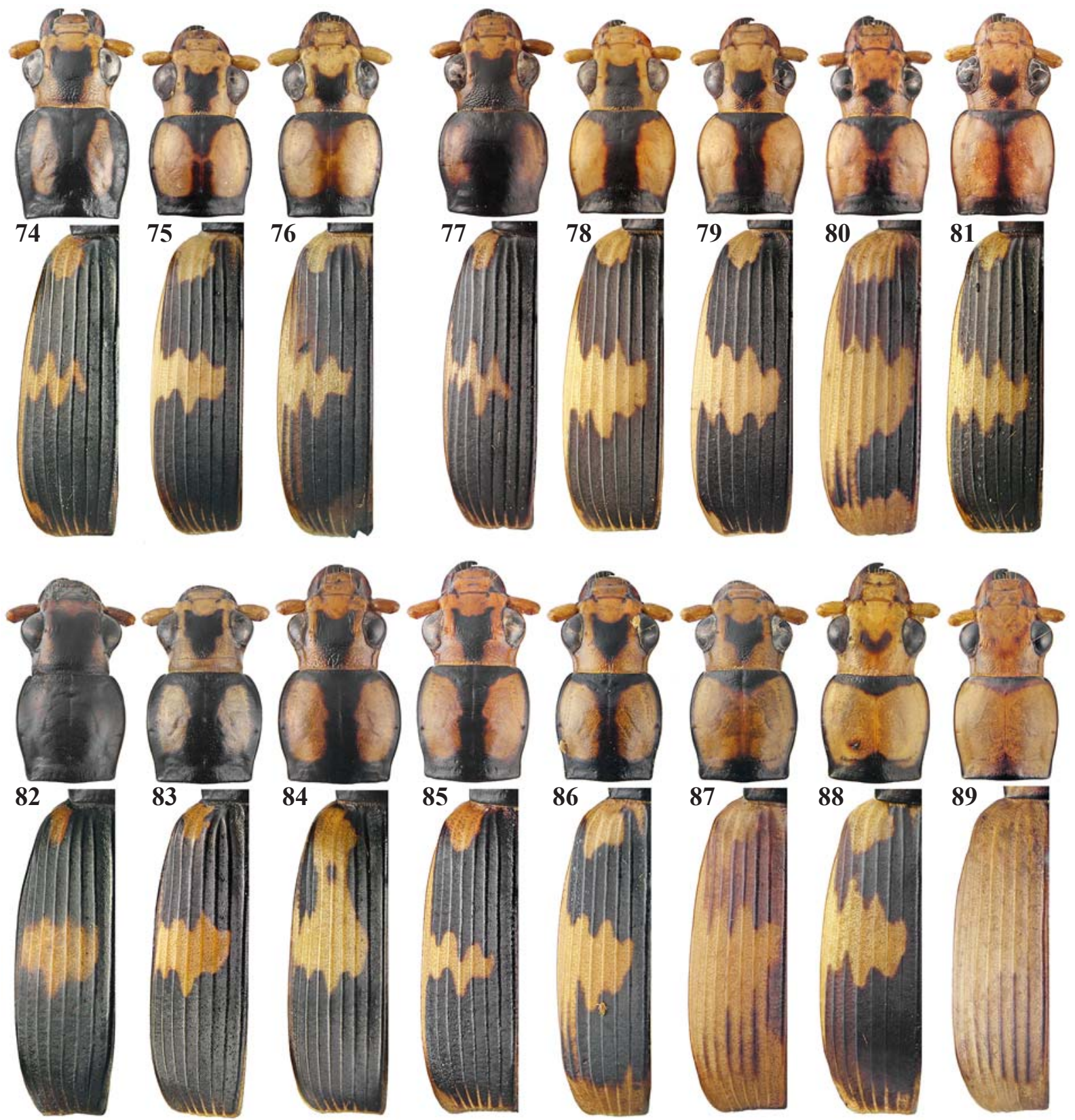

Figs 74-89. Stenaptinus spp., variation of dorsal pattern in specimens from different localities: 74-76 - S. javanus; 77-81 - S. fimbriatus; 82-89 - S. agnatus; 74 - Loc Bao; 75-76 - Thailand; 77 - Sumatra; 78-79, 88 - Cambodia; 80-81, 85-87 — Cat Tien NP; 82-83 - Song Thanh NP; 84 - Kon Plong Distr.; 89 - Nho Quan env.

Рис. 74-89. Stenaptinus spp., изменчивость окраски верха у особей из разных местонахождений: 74-76 - S. javanus; 77-81 S. fimbriatus; 82-89 - S. agnatus; 74 — Локбао; 75-76 — Таиланд; 77 — Суматра; 78-79, 88 — Камбоджа; 80-81, 85-87 — нац. парк Каттьен; 82-83 - нац. парк Сонгтхань; 84 - округ Конплонг; 89 - окр. Нхокуан. 
Additional material: $3 \sigma^{\gamma} \sigma^{\gamma}, 5+0$ (SIEE), Vietnam, Dongnai Province, Nam Cat Tien National Park, $11^{\circ} 25^{\prime} 18^{\prime \prime} \mathrm{N} / 107^{\circ} 25^{\prime} 44^{\prime \prime} \mathrm{E}$ at light HQL-450, 3-12.VI.2005 (D. Fedorenko); $\sigma^{7}$, same data except 18-25.X.2004; $\sigma^{7},+$, (MSPU), Quang Binh Province, Minh Hoa [=Quy Dat] Distr., env. Yen Hop, Ke Bang National Park, 13.IV.1999 or 24-30.III.1999 (S. Kruskop); O (SIEE), Cambodia, Stung-Treng, 3.XII.2017 (A. Kompantsev); + , Kep Province, env. Kep, $10^{\circ} 29^{\prime} 56^{\prime \prime} \mathrm{N} / 104^{\circ} 17^{\prime} 39^{\prime \prime} \mathrm{E}$, h 40 m, at light, 13.VI.2014 (I. Melnik); $\sigma^{\prime}$ (SIEE), Sumatra, Berastagi, lake Toba, 10.VI.214 (A Vasiliev); W Sumatra Province, $\sim 6 \mathrm{~km}$ NNW of Bukittinggi, $0^{\circ} 14^{\prime} 47^{\prime \prime} \mathrm{N} / 100^{\circ} 20^{\prime} 49^{\prime \prime} \mathrm{E}, \mathrm{h}=900 \mathrm{~m}, 22 . \mathrm{II} .2017$ (A. Prosvirov).

Genitalia examined in seven males and three females.

DIAGNOSIS. Very similar to $S$. javanus in body shape, proportions (Table) and colour pattern (Figs 77-81), except for the following characters: Elytra rather short in females. Black patch on vertex parallel-sided or broadened toward pronotum; pronotal pale spots large, leaving pronotum very narrowly to indistinctly infuscated along sides. Tergite VII with 10-13 apical setae which are very strong and apically hooked in female. Aedeagus (Figs 48-50, 53): apex of median lobe with a distinct ventro-apical carina, in dorsal view long, triangular, with tip in form of a minute pointed beak; internal sac symmetrical, with a large duble basal bulb and body reduced much in size.

REDESCRIPTION. BL 16.5-20 mm. Body pattern variable (Figs 77-81): vertex with black spot varying between large U-shaped, mostly extended to pronotum or occupying entire neck, and rather small pentagonal, with neck more or less infuscated medially; elytral pale transverse band, narrow to wide, strongly dentate and mostly reaching lateral margin.

Head and pronotum pilose and punctate as in S. agnatus, except that setigerous punctures are much less distinct on the latter; elytral pilosity very sparse yet traceable, being often arranged into an irregular row in each interval.

Pronotum subcordate, as long as wide, broadest almost medially. Base distinctly wider than apex; basal angles mostly slightly obtuse and blunt. Lateral bead and groove fine, obliterate in front of basal angles, sometimes (specimen from Java) entire.

Abdomen (Figs 7, 17): Tergite VII with dense and rather fine double punctation, larger punctures being small. Sternite VIII with lateral apical setae strong and curved dorsad in female.

Female gonocoxite IX long, subclavate, slightly curved, apically obtuse (Fig. 63). Spermatheca distinctive due to receptacle apically incrassate, bulbous (Fig. 66).

GEOGRAPHIC DISTRIBUTION. Southern India to Indochina (supposedly, except northern parts) south to the Greater Sunda Isles. The species range is similar to that of $S$. javanus, yet obscured by confusion of $S$. fimbriatus, $S$. agnatus $S$. javanus and $S$. sumatrensis sp.n. The species is not uncommon in southern Vietnam, yet no record in Central or northern Vietnam.

HABITATS AND HABITS. No data, except that most specimens examined were collected at light in lowlands, in southern Vietnam, together with specimens of other congeners (see the respective section under $S$. agnatus).

COMMENTS. The species was described based on three syntypes from either southeastern India or Thailand, or Java; that from India is here designated as the lectotype.

Unlike the other species of the group, $S$. fimbriatus is sexually dimorhic in body proportions. In particular, the elytra are slightly longer and narrower in males than in females: EL/EW 1.52-1.65 (1.58) vs. 1.46-1.58 (1.50) and EW/PW 1.65-1.86 (1.78) vs. 1.78-1.97 (1.90), respecively $\left(4 \bigcirc^{\top} \sigma^{\top}\right.$ and $4+9$ from the Cat Tien NP, $2 \sigma^{\top} \sigma^{\top}$ from Sumatra, and 290 from Cambodia measured).
Besides, I provisionally determine three male specimens [Natural History Museum, 2014] from the Malay Peninsula as $S$. fimbriatus, with reservation that at least some of them may belong to $S$. sumatrensis sp.n. These are from: (1) 'Perak', without exact locality (NHMUK 013460710); (2) Parit Buntar, Perak, 4.XI.1931, H.T. Pagden (NHMUK 013460706); (3) Langkawi Is, Kedah (West Coast), 14.IV.1928 (NHMUK 013460711).

\section{Stenaptinus dongnaiensis Fedorenko, sp.n.} Figs $51,55,72$, 106-107.

MATERIAL. Holotype $\sigma^{7}$ (ZMMU) with label 'S[outhern] Vietnam, N[orthern part of] Dongnai Province, Nam Cat Tien Nat[ional]. Park, Exped[ition of]. Russ[ian].-Vietnamese Tropical Centre, at light HQL450, 21.X.2004, leg. D.Fedorenko'. Paratypes, $2 \sigma^{7} \sigma^{\top}$ (SIEE), same data except for dates 5.XII.2004 or 17.VI.2005. - Aedeagus examined in all males.

DIAGNOSIS. No difference from $S$. fimbriatus except in colour pattern (Figs 72, 106-107), and aedeagus is distinctive. Specifically, vertex with a small, subtransverse pentagonal to rhomboidal black patch; pronotal pale spots large, separated or fused along midline, reaching lateral margin, so that pronotum laterally pale or with lateral bead vaguely infuscated in basal half; elytral transverse band wide. Aedeagus (Figs 51, 55): apex of median lobe barely tapered in lateral view (vs. triangular in $S$. fimbriatus), similar yet more symmetrical in dorsal view. Internal sac with the body much larger than proximal basal bulbs; these projecting laterad and well-visible in dorsal view.

DESCRIPTION. BL 17.1-18.5 mm; pronotum broadest two fifths from apex, basal angles right or slightly obtuse, lateral bead and groove very fine throughout. For the other details see the diagnosis.

GEOGRAPHIC DISTRIBUTION. Known from the type locality only.

NAME. Topotypic.

HABITATS AND HABITS. The three specimens have been collected at light, at the edge of tropical monsoon forest about $100 \mathrm{~m}$ distant from the Dong Nai River.

COMMENTS. The new species is very close to $S$. fimbriatus and very similar to its paler specimens.

\section{Stenaptinus sumatrensis Fedorenko, sp.n. \\ Figs 4, 14, 52, 54, 56, 70, 73, 108-109.}

MATERIAL. Holotype $\sigma^{\prime}$ (ZMMU) labeled 'Sumatra, Barat Province, Maninjau vill., $00^{\circ} 17^{\prime} 09^{\prime \prime} \mathrm{N} / 100^{\circ} 13^{\prime} 54^{\prime \prime} \mathrm{E}, \mathrm{h}=498 \mathrm{~m}, 18$ 19.XII.2014, leg. I. Melnik'. See also 'comments' to $S$. fimbriatus.

DIAGNOSIS. No differences from melanistic specimens of $S$. fimbriatus, except that aedeagus is distinctive and elytra shorter.

DESCRIPTION. Macropterous species (Fig. 73, 108109). BL $16 \mathrm{~mm}$. Head pale, with a U-shaped patch on vertex which is parallel-sided and merged into black neck. Pronotum black, each side with a small, somewhat vague oblong spot almost reaching lateral margin. Elytra black, each with pale pattern consisting of a small humeral spot, a very narrow, vague, zigzag patch spanning ridges 5 to 7 , extreme apical margin, and apices of elytral ridges just in front. Dorsum glabrous, except for a few setules behing supra-ocular seta, very sparse pilosity at pronotal base and apex, and individual setules scattered over elytral disc; this latter also with rather dense yet nearly imperceptible microscopic ciliae.

Pronotum as wide as long, broadest just in front of middle, slightly convex at basal margin and sinuate at apex; sides subsinuate a fifth from base. Base slightly wider than apex; lateral bead and groove very fine, almost obliterate in front of basal angles; these very slightly obtuse and slightly blunted. 
Abdomen (Figs 4, 14): tergite VII finely and rather unevenly punctate, with larger punctures small and fine punctures missing here and there.

Aedeagus (Figs 52, 54) as for S. dongnaiensis sp.n., except for internal sac having the body larger and proximal basal bulb barely divided into two, indistinctly projecting laterad and thence invisible in dorsal view.

Female genitalia and reproductive tract (Figs 56, 70) as for $S$. fimbriatus, except that gonocoxite IX is slightly shorter and wider.

GEOGRAPHIC DISTRIBUTION. Known from the type locality only.
NAME. Topotypic.

HABITATS AND HABITS. No data.

COMMENTS. The holotype is hardly different from melanistic specimens of $S$. fimbriatus (those with infuscated neck), but aedeagus is very similar to that of $S$. dongnaiensis sp.n. This suggests that $S$. sumatrensis sp.n. and $S$. dongnaiensis sp.n. may only be subspecies of one species and allows me to provisionally identify a female specimen from Java (100 km of Djakarta, Mt. Pangrango, 1000 m, 914.X.1999, A.V. Gorokhov leg., ZISP) as sumatrensis sp.n., with reservation that it may be $S$. fimbriatus. This female (Figs 4, 14, 56, 70, 109) has the tergite VII with apical setae
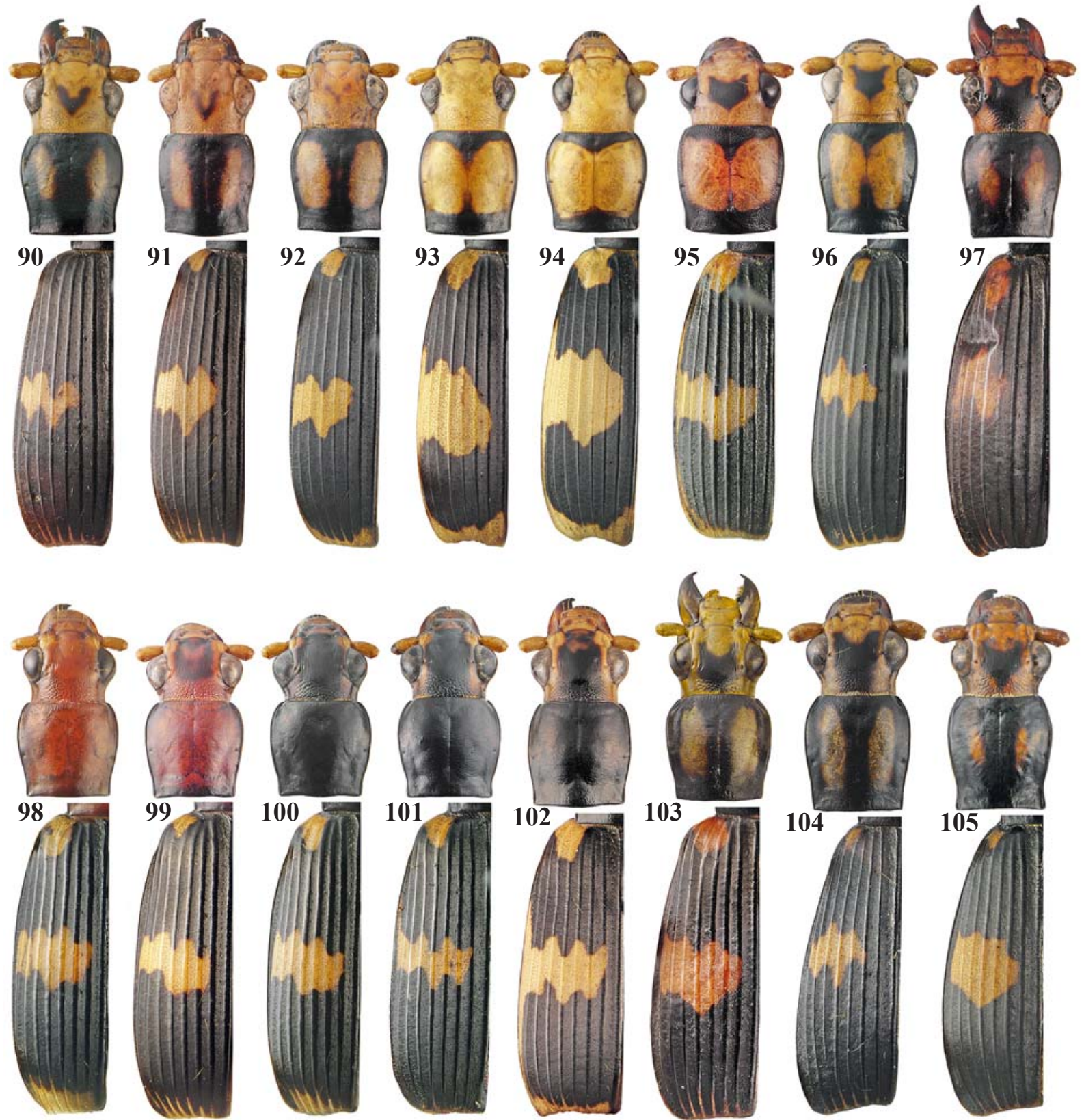

Figs 90-105. Stenaptinus spp., variation of dorsal pattern in specimens from different localities: 90-94 - S. consularis; 95 - S. marginicollis; 96-97, 103-105 - S. stenoderus; 98-102 - S. lissoderus; 90-91, 101-102, 104 — Northern Thailand; 92 — Gia Lai Prov.; 93, 96 - Pu Hoat NP; 94 - Ke Go NP; 97 — Tam Dao; 98-100, 103 — India; 105 — Song Thanh NP.

Рис. 90-105. Stenaptinus spp., изменчивость окраски верха у особей из разных местонахождений: 90-94 - S. consularis; 95 S. marginicollis; 96-97, 103-105 - S. stenoderus; 98-102 - S. lissoderus; 90-91, 101-102, 104 - северный Таиланд; 92 - Пров. Зялай; 93, 96 - нац. парк Пухоат; 94 - нац. парк Кего; 97 - Тамдао; 98-100, 103 — Ирдия; 105 - нац. парк Сонгтхань. 
less strongly curved at apices and the gonocoxite IX slightly shorter and wider than in female $S$. fimbriatus.

\section{Stenaptinus marginicollis (Motschulsky, 1854)}

Figs 10, 20-22, 62, 68, 95.

Motschulsky, 1854: 44 (Pheropsophus; Pekin [= Beijing] env.); Chaudoir, 1876: 43; Schauberger, 1923: 53.

MATERIAL. The only pinned specimen, of (ZMMU) with a mishaped yellow circle and a handwritten label 'Pheropsophus marginicollis/ China bor. Motsch', designated here as lectotype. The specimen is damaged by larval Dermestidae, resulting in the antennomeres 4-11, left hind leg and apical 1/4-1/6 elytra lost.

Additional material (SIEE): $20^{7} \sigma^{7}, 2+9$, N China, Gansu Province, Liupan Mts $10 \mathrm{~km} \mathrm{~W}$ of Shangguan, $35^{\circ} 03^{\prime} \mathrm{N} / 106^{\circ} 29^{\prime} \mathrm{E}$, VI.2005 (V. Siniaev team). - Genitalia examined in two males and one female.

DIAGNOSIS. A robust apterous species; pronotum pale except along margins; black patch on vertex transverse, parallel-sided, with anterior and posterior margins V-shaped; mandibles, tarsi and antennomeres 5-11 distinctly infuscated. Elytra rounded on sides, slightly wider apically than basally, with ridges as wide as intervals and shiny due to obliterate microsculpture. Tergite VII with 14-17 rather short and more or less curved apical setae in female. Apex of aedeagus median lobe flattened dorsoventrally, in dorsal view rounded apically, without ventroapical carina (Figs 21-22). Internal sac in lateral view with body wide and convex at frontal and caudal margins; microtrichia poorly developed.

REDESCRIPTION. BL 16.3-18.7 mm. Body (Fig. 95) robust. Head and pronotum yellow, with patch on vertex, pronotal base, apex, and rather narrow lateral margins black; patch on vertex parallel-sided, slightly transverse, with anterior and posterior margins $\mathrm{V}$-shaped, or pentagonal and somewhat stellate due to its sides concave. Elytral humeral spot rather large, transverse median band rather wide and unevenly dentate, with black or yellow colour extended along ridge 5 fartherst apicad, along lateral margin slightly basad and along interval 8 to a more or less widely pale apical margin, with extreme lateral edge infuscated or not. Femoral apices black, mandibles dark brown to black, tarsi, antennomeres $5-11$, apices of 1-4, sometimes entire antennomere 3 , brown; often also tibiae more or less infuscated toward apices except externally.

Dorsum glabrous, except for individual setules over elytral disc; head and pronotum densely and finely to conspicuously rugulose. Microsculpture very superficial to obliterate on head and pronotum, coarse on sides of pronotal base. Elytral intervals with very dense and short carinules, ridges shiny due to obliterate microsculpture.

Pronotum quadrate, subcordate, barely shorter than wide, broadest a third from apex, with sides poorly rounded, subsinuate a fifth from base. Base slightly wider than apex, basal margin slightly convex, apical margin truncate or barely convex, basal angles obtuse and more or less blunt. Lateral bead and groove very fine, obliterate basally.

Abdomen (Figs 10, 20): tergite VII with moderately dense double punctation, with larger punctures coarse, fine punctures very small yet evenly spaced and well traceable. Sternite VIII bisetose or trisetose in male, with $c a$. 14 strong and straight apical setae in female.

Female gonocoxite IX strongly curved and slightly narrowed apicad (Fig. 62). Spermathecal receptacle tumid, bulbous and rather small (Fig. 68).

GEOGRAPHIC DISTRIBUTION. Northern and eastern China (Gansu, Zhejiang, and Liaoning provinces; Peking, Shanghai). All records of this species in Vietnam [Park et al., 2006] refer to different species.

HABITATS AND HABITS. No data, except that the specimens listed have been collected together with those of $S$. jessoensis.

COMMENTS. The female lectotype is distinctive from the other examined specimens of this species in only having
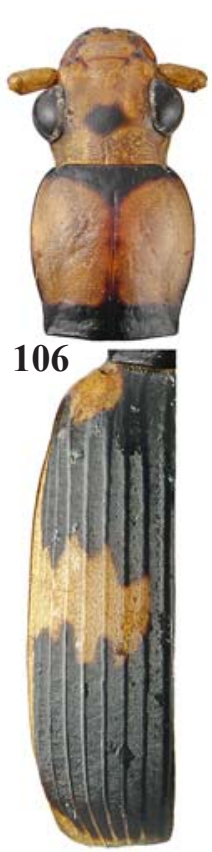
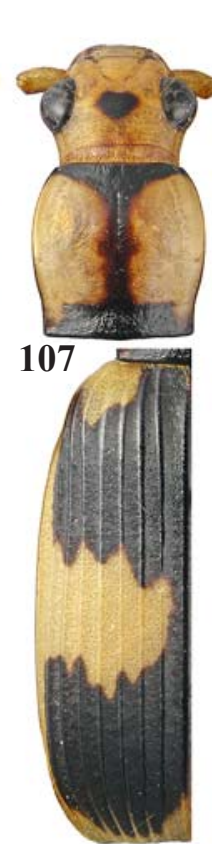
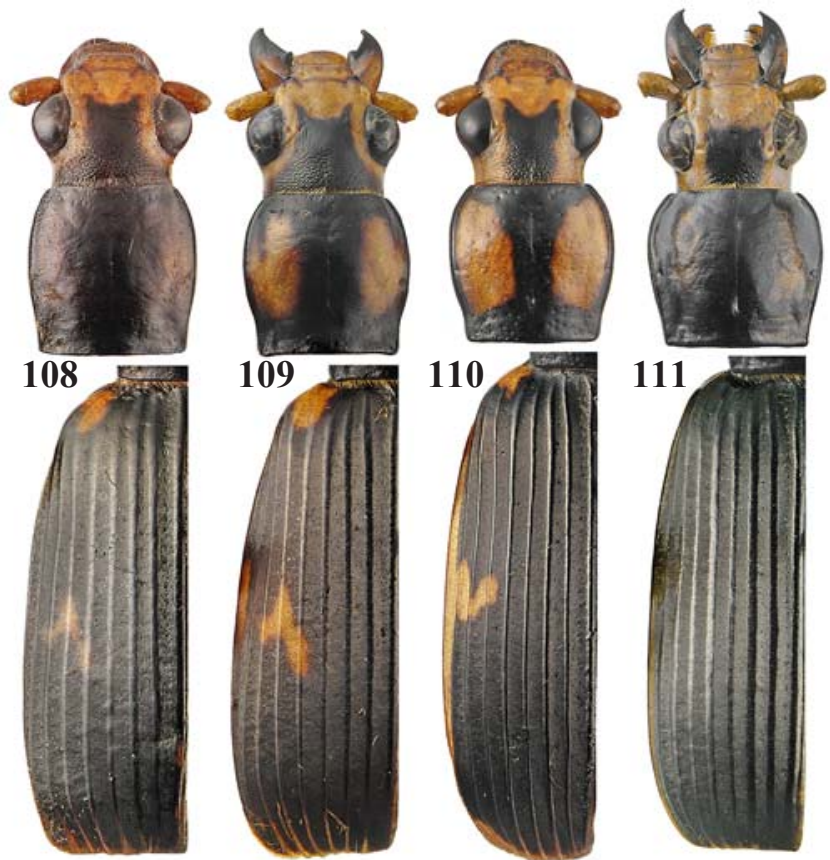

Figs 106-111. Stenaptinus spp., dorsal pattern: 106-107 - S. dongnaiensis sp.n., holotype and paratype; 108-109 - S. sumatrensis sp.n., holotype and paratype; $110-$ S. madagascariensis; $111-$ S. fumigatus.

Рис. 106-111. Stenaptinus spp., окраска верха: 106-107 — S. dongnaiensis sp.n., голотип и паратип; 108-109 - S. sumatrensis sp.n., голотип и паратип; $110-S$. madagascariensis; $111-$ S. fumigatus. 


\begin{tabular}{|c|c|c|c|c|}
\hline 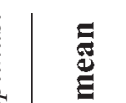 & 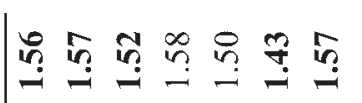 & in & 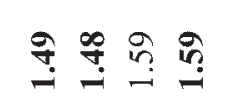 & 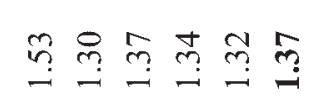 \\
\hline$\sum_{i=1}^{3}$ & 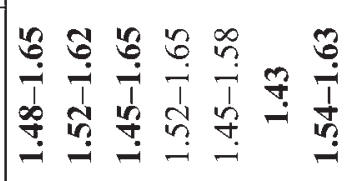 & 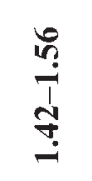 & 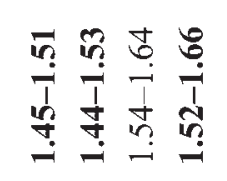 & $\begin{array}{lll} \\
0\end{array}$ \\
\hline 离 & 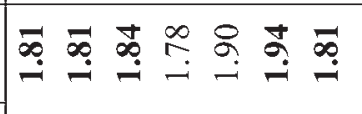 & $\hat{S}$ & 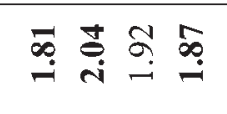 & 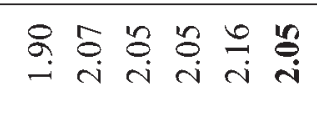 \\
\hline 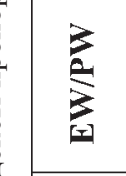 & 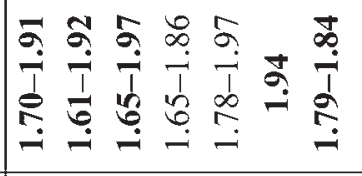 & 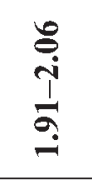 & 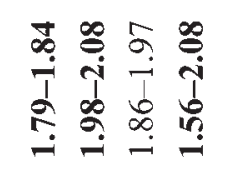 & 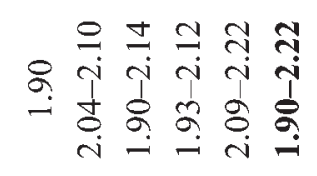 \\
\hline 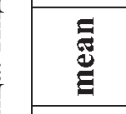 & $\cong \stackrel{9}{=}$ & $\dddot{7}$ & $\stackrel{\circ}{9} \stackrel{\circ}{\longrightarrow} \stackrel{9}{\longrightarrow}$ & 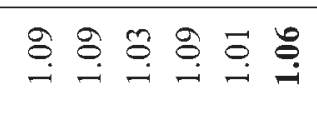 \\
\hline 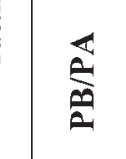 & 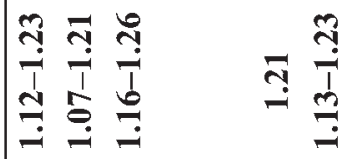 & 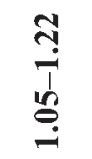 & 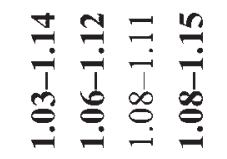 & 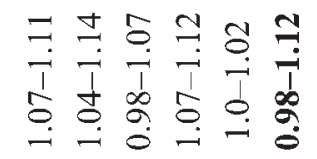 \\
\hline 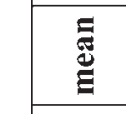 & 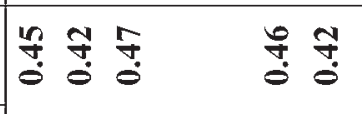 & $\begin{array}{c}\infty \\
0 \\
0\end{array}$ & 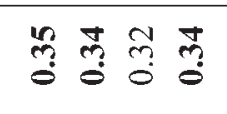 & 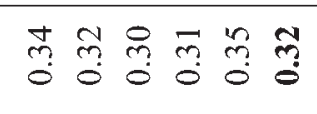 \\
\hline 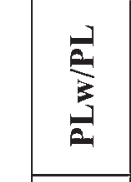 & 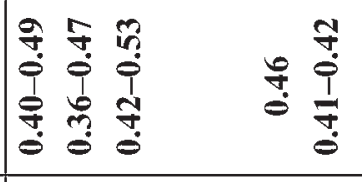 & 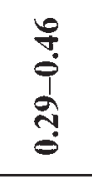 & 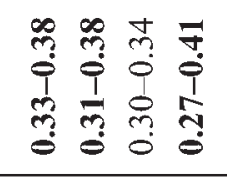 & 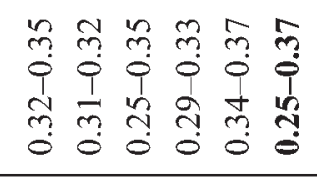 \\
\hline 焉 & $\stackrel{g}{i} \dot{\Xi}$ & $\stackrel{\leftrightarrow}{\stackrel{2}{*}}$ & 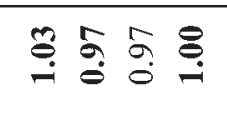 & 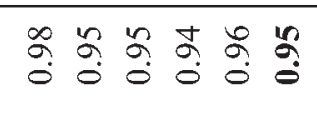 \\
\hline 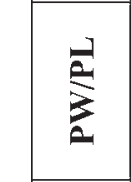 & 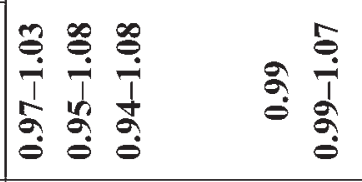 & 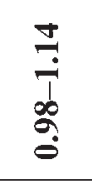 & 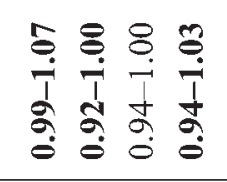 & 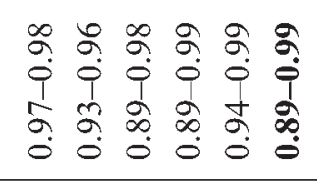 \\
\hline 离 & 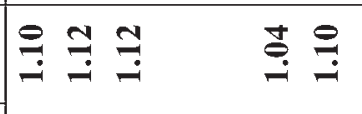 & $\stackrel{\leftrightarrow}{\stackrel{2}{9}}$ & 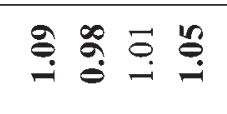 & 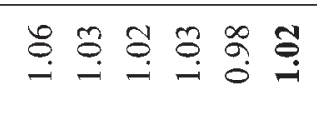 \\
\hline 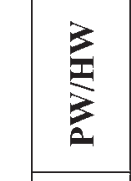 & 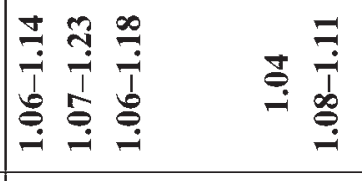 & 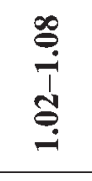 & 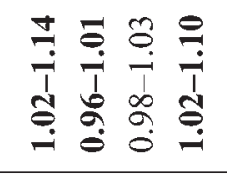 & 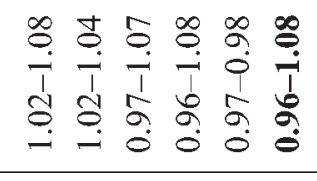 \\
\hline$=$ & 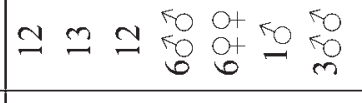 & $r$ & $\tan a b$ & Nas in 8 \\
\hline 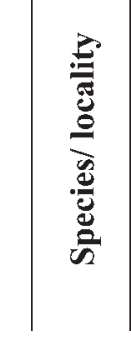 & 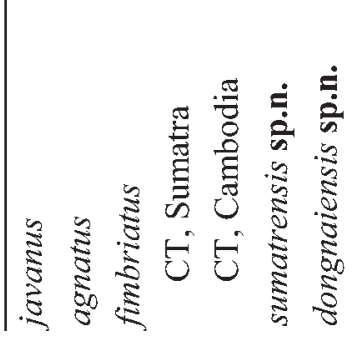 & 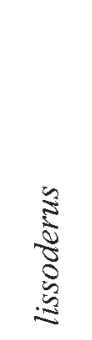 & 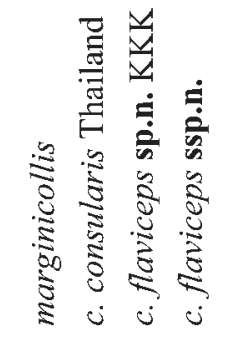 & 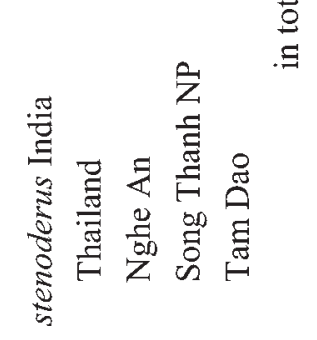 \\
\hline
\end{tabular}


the elytral pale pattern overdeveloped, with black colour reduced to a narrow zigzag between large humeral spot and wide median band. This band is subequally dentate, anteriorly at the ridges 4, 6 and 8 , posteriorly at the ridges $3,5,7$ and at the lateral edge. It touches the sutural ridge and reaches lateral margin, being extended along lateral edge to humeral spot and along interval 8 in its outer half to rather a widely pale apex, thus leaving extreme lateral margin black medially and at the apex of the humeral spot.

This species was redescribed by comparing it with $S$. suensoni in many points [Schauberger, 1923]. Schauberger also described the aedeagus of $S$. marginicollis for the first time and reported the species from Shanghai, Hangchow (= Handzhou, Zhejiang) and Mukden (= Shenyang, Liaoning), China.

Aknowledgements. I am much obliged to Dr. Roman Dudko (SZM), Alexei Gusakov (ZMMU), Dr. Boris Kataev (ZISP), and Dr. Kirill Makarov (MSPU) for the loan of material under their care, and to Azadeh Taghavian-Azari (MNHN) and $\mathrm{Yu}$. Sundukov (EASC) for high-resolution images of type and non-type specimens. My sincere thanks also to Alexander Kompantsev (SIEE), Igor Melnik (Moscow), Dr. Natalya Belyaeva and Dr. Alexander Prosvirov (The Moscow State University) for donating specimens and to Dr. Alexey Abramov (ZISP) and Dr. Nikolay Poyarkov (The Moscow State University) for their assistance in collecting beetles in Vietnam. This study was funded by the Presidium of the Russian academy of sciences, Program No.41 "Biodiversity of natural systems and biological resources of Russia".

\section{References}

Andrewes H.E. 1923. On the types of Carabidae described by Schmidt-Goebel in his Faunula Coleopterorum Birmaniae // Trans. Ent. Soc. Lond. P.1-63.

Andrewes H.E. 1924. Mission Guy Babault dans les provinces centrales de l'Inde et dans la région occidentale de l'Himalaya 1914. Résultats scientifiques. Insectes Coléoptères, Carabidae. Paris, P.1-123, pl.1-4.

Andrewes H.E. 1926. A catalogue of Philippine Carabidae// Philipp. J. Sci. Vol.31. No.3. P.345-361.

Andrewes H.E. 1929. Fauna Sumatrensis. (Beitrag Nr.64). Carabidae (Col.) // Tijdschr. Ent. Vol.27. P.304-340.

Andrewes H.E. 1930. Catalogue of Indian Insects. Calcutta: Government of India. XXII+389+4 pp.

Andrewes H.E. 1933. A Catalogue of the Carabidae of Sumatra // Tidschr. Entomol. Jg.76. S.319-382.

Bates H.W. 1889. Contributions a la faune Indo-Chinoise. 3e Mémoire (1). Carabidae // Ann. Soc. Ent. France. 6e Sér. 2. T.9. P.261-286.

Bates H.W. 1892. Viaggio di Leonardo Fea in Birmania e regione vicine. XLIV. List of the Carabidae // Ann. Mus. Stor. Nat. Genova. Ser. 2. Vol.12 (32). P.267-428.

Chaudoir M. 1850. Mémoire sur la famille des Carabiques, 2 // Bull. Soc. Nat. Mosc. T.23. N.1. P.1-85.

Chaudoir M. 1876. Monographie des Brachynides // Ann. Soc. Ent. Belg. T.19. P.11-104.

Csiki E.v. 1933. Carabidae. Harpalinae VIII // W. Junk, S. Schenkling (Hrsg.). Coleopterorum Catalogus. Berlin: W. Junk. Vol.3. Pt.126. S.1599-1933.
Darlington P.J. 1968. The Carabid beetles of New Guinea Part III. Harpalinae (continued): Perigonini to Pseudomorphini // Bull. Mus. Harvard. Vol.137. No.1. P.1-253.

Dejean P.F.M.A. 1825. Species général des Coléoptères de la Collection de M. le Comte Dejean. T.1. Paris. XXX+463 pp.

Dupuis P. 1913. H. Sauter's Formosa ausbeute Carabidae // Ann. Soc. Ent. Belg. T.57. P.418-425.

Dupuis P. 1914: H. Sauter's Formosa ausbeute Carabidae // Ann. Soc. Ent. Belg. T.58. P.29-36.

Fedorenko D.N. 2020. Stenaptinus (Coleoptera: Carabidae: Brachininae) of Vietnam. Note $1 / /$ Russian Entomol. J. Vol.29. No.4. P.361-376.

Giachino P.M. 2005. The genus Pheropsophus Solier, 1833 in New Guinea (Insecta, Coleoptera, Carabidae, Brachininae) // Spixiana. Bd.28. No.3. S.223-257.

Habu A. 1967. Carabidae Truncatipenne group (Insecta, Coleoptera). Fauna Japonica. Biogeographical Society of Japan. Tokyo. XIV $+338 \mathrm{pp}+27 \mathrm{pl}$.

Habu A. 1984. Revised and supplementary notes on and descriptions of the Truncatipennes group of Japan (IV) (Coleoptera, Carabidae) // Ent Rev. Japan. Vol.39. No.2. P.101-138.

Hrdlička J. 2017. Brachininae // I. Löbl, A. Smetana (eds).. Catalogue of Palearctic Coleoptera. Vol.1. Archostemata-Myxophaga - Adephaga. Stenstrup: Appolo Books. P.471-480.

Hrdlička J. 2019. A contribution to the tribe Brachinini (Coleoptera: Carabidae) - VIII. A new species of Brachinini from South and South-East Asia and New Guinea // Stud. Rep. Mus. PragueEast, Taxon. ser. Vol.15. No.1. P.75-89.

Jedlička A. 1964. Monographie der Truncatipennen aus Ostasien. Lebiinae - Odacanthinae — Brachininae (Coleoptera, Carabidae) // Ent. Abhandl. Mus. Dresden, Dresden. [1963-1964]. Bd.28. Nr.7. S.305-579.

Kuiper P.N. 2016. The Early Dutch Sinologists: a study of their training in Holland and China, and their functions in the Netherlands Indies (1854-1900). PhD Thesis, Leiden University, Leiden. P.I-XVII, 1-1035.

Lafer G.Sh. 1973. [On little-known ground beetles (Coleoptera, Carabidae) of the Maritime Province and their zoogeographic characteristics] // Entomol. Obozr. Vol.52. P.845-855 [in Russian].

Lafer G.Sh. 1989. [Fam. Carabidae - The ground beetles] // P.A. Lehr (ed.). [Opredelytel nasekomykh Dalnego Vostoka SSSR. T.3. Zhestkokrylye, ili zhuki]. Pt.1. Leningrad: Nauka. P.71222 [in Russian].

Lafer G.S., Zolotarenko G.S. 1971. [Pheropsophus javanus, a new carabid species for the fauna of the USSR] // A.I. Cherepanov (ed.). Novye i maloizvestnye vidy fauny Sibiri. No.4. Novosibirsk: Nauka. P.64-70 [in Russian].

Louwerens C.J. 1953. Carabidae (Col.) from the Sunda Islands // Verh. Naturf. Ges. Basel. Bd.64. Nr.2. P.305-325.

Maindron M. 1906. Description d'une nouvelle espèce de Pheropsophus et remarques sur ce genre // Bull. Soc. Ent. France. P.15-16.

Motschulsky V. 1854. Diagnoses de Coléoptères nouveaux trouvés par M.M. Tatarinoff et Gaschkewitsch aux environs de Pekin // Etud. Ent. 1853. P.44-51.

Natural History Museum 2014. Dataset: Collection Specimens. Nat. Hist. Mus. Data Portal (data.nhm.ac.uk). https://doi.org/10.5519/ 0002965.

Schauberger E. 1923. Ein neuer Pheropsophus aus China // Ent. Anzeiger. Jg.3. N.5. S.53-54.

Schmidt-Göbel H.M. 1846. Faunula Coleopterorum Birmaniae, adjectis nonnulis Bengaliae indigenis. P.I-VIII, 1-94, P1.I-III.

Venugopal A., Thomas S. 2019. Bombardier beetles of the genus Pheropsophus Solier 1833 (Carabidae: Brachininae: Brachinini) from Indian subcontinent // Zootaxa. Vol.4608. No.1. P.65-89. 